University of Rhode Island

DigitalCommons@URI

Open Access Dissertations

2016

\title{
"A Peculiar Power of Perception": Scottish Enlightenment Rhetoric and the New Aesthetic of Language
}

Rosaleen Greene-Smith Keefe

University of Rhode Island, rgreenesmith@my.uri.edu

Follow this and additional works at: https://digitalcommons.uri.edu/oa_diss

\section{Recommended Citation}

Greene-Smith Keefe, Rosaleen, "'A Peculiar Power of Perception": Scottish Enlightenment Rhetoric and the New Aesthetic of Language" (2016). Open Access Dissertations. Paper 464.

https://digitalcommons.uri.edu/oa_diss/464

This Dissertation is brought to you for free and open access by DigitalCommons@URI. It has been accepted for inclusion in Open Access Dissertations by an authorized administrator of DigitalCommons@URI. For more information, please contact digitalcommons-group@uri.edu. 
“A PECULIAR POWER OF PERCEPTION”: SCOTTISH

ENLIGHTENMENT RHETORIC AND THE NEW

AESTHETIC OF LANGUAGE

BY

ROSALEEN GREENE-SMITH KEEFE

A DISSERTATION SUBMITTED IN PARTIAL FULFILLMENT OF THE REQUIREMENTS FOR THE DEGREE OF

DOCTOR OF PHILOSOPHY

IN

ENGLISH LITERATURE

UNIVERSITY OF RHODE ISLAND

2016 


\title{
DOCTOR OF PHILOSOPHY DISSERTATION \\ OF ROSALEEN GREENE-SMITH KEEFE
}

APPROVED:

Dissertation Committee:

\author{
J. Jennifer Jones \\ Stephen J. Barber \\ Cheryl Foster \\ Nasser H. Zawia \\ DEAN OF THE GRADUATE SCHOOL
}

UNIVERSITY OF RHODE ISLAND

2016 


\begin{abstract}
This dissertation is an inquiry into the ways rhetoric, as the study of the art of language use, and literature, as the art of written language, were coherently theorized in Enlightenment Scotland to articulate the complex nature of language and its inherent relationship to the human mind and its faculties. The chapters contained in this manuscript dissertation are previously published studies in eighteenth-century Scottish rhetorical theory, examining the multiple and sometimes contradictory legacies of this important body of work on language pedagogy, philosophy of mind and language, and political theory. These studies offer new grounds for examining the legacies of Scottish rhetoric, amongst them the creation of a new aesthetic of language arising from the moral sentiments tradition.
\end{abstract}




\section{ACKNOWLEDGEMENTS}

I would like to gratefully and warmly acknowledge the excellent guidance of my graduate dissertation committee.

My entire committee from the outset to the completion of this project has been a source of strong and consistent professional guidance, advocacy, and mentoring, for which I extend the warmest thanks. Prof. Jennifer Jones, my major professor, has been inspirational in her demonstration of expertise and highest expectation balanced by genuine engagement and personal support. Her presence as a model and resource has guided my work in more ways than can be accounted for here. She, and this entire committee, deserve a commendation not only for the highest level of collaboration and expertise, but also for single-handed striking a blow against the inequalities which can accompany women who are parents in academia. Prof. Stephen Barber's brilliant lines of counter-inquiry have shaped my internal voice inestimably; to him I owe much more of my interior landscape than he will ever know. Prof. Cheryl Foster worked tirelessly to expand my philosophical accountability and expansiveness, her philosophical vision and expression of what it means to be a professor has become me a powerful representamen of these things. I also thank Prof. Andrea Rusnock for her keen historical questioning, and also professional insight and support. And finally, to Prof. Jeremiah Dyehouse I give the profoundest debt of gratitude, for his wisdom, perception, and belief. This team of mentors has worked consistently, selflessly, and with great solidarity for the benefit of my growth as a scholar and a teacher.

I would like to thank also the Richard Beaupre Hope and Heritage Award for 
its generous support of my participation in the Petrus Ramus Conference 2008 at the University of St. Andrews in Fife, Scotland.

I also express love and gratitude to my colleagues and mentors near and far who have been active participants in the creation of the works included in this dissertation, or whose personal support was welcome and necessary, especially William Donaldson, Gordon Graham, Rebekah Greene, Gesa Kirsch, Sarah Kruse, Ryan Shea, Jan Swearingen, Ruth Perry, Steven Reid, and Emma Annette Wilson. 


\section{DEDICATION}

I lovingly dedicate this work to my spouse for the countless hours of personal, professional, and financial sacrifice and support it represents. I hope someday I may support his writing in the same manner. I include also my parents, for their endless interest and support, my siblings, for tolerating and humoring me, and of course, my children, who will be too little to remember all the hours they spent at the park so that I could work in peace. 


\section{Preface}

In the dominant tradition of rhetorical and literary history, Enlightenment Scottish rhetoric culminates with the creation of Hugh Blair's Regius Chair of Rhetoric and Belles lettres at Edinburgh University in 1762. This historical moment marks the official beginning of the study of literature as an academic field, and inaugurates literary criticism as the primary means of access to the literary arts. Essentially, this dissertation argues that Scottish rhetoric, and its belles lettres tradition, enjoys more trajectories than the one extensively examined in the accepted version of the legacy of Hugh Blair. I suggest that if the pedagogical and critical posterity of the Chair of Rhetoric and Belles lettres is temporarily ignored, one may look with less prejudice at the vastly interconnected philosophical vision in which the new rhetoric played a central role, and see that there are, and there were, multiple trajectories to this theory of language that are equally important to the legacy of Scottish belles lettres. This argument calls attention to some of the lesser-examined legacies of Scottish rhetoric, amongst them the creation of a new aesthetic of language arising from the moral sentiments tradition. The belles lettres tradition represents one branch of new aesthetic of language arising from the Scottish moral sentiments tradition, but it is more closely associated with an aesthetic of reading. Another, perhaps more important, corollary between the moral sentiments tradition and the philosophy of language which developed in Enlightenment Scotland is a new aesthetic of writing, and particularly, of poetry. This new aesthetic, found in writers such as Robert Fergusson and Robert Burns, values the contingent and particular as moral contexts through which to create shared experience and moral consensus, and turns, 
quite naturally, as did the use of vernacular language. This is but one of the many exciting new ways of looking at the literary legacy of the Scottish Enlightenment, long overdue for a critical re-examination.

All pieces included in this manuscript format dissertation share the goal of challenging the accepted narratives within literary and rhetorical histories of this period, particularly surrounding the practices of literary criticism attached to the belles lettres tradition. These challenges in turn help to create a platform for a new critique of the relationship between rhetoric, philosophy, and literature in this period based on their synchronicity, and therefore encompassing literary achievements that would have seemed previously at odds, though contemporaneous. Susan Manning, in Poetics of Character (2013), cogently argues for precisely this type of fresh examination of the Scottish Enlightenment. My dissertation takes up Susan Manning's call to "explore the potential of an alternative (perhaps complementary) literary history alert to nuances of connection and comparison" (xii), not, in this case to examine the rhetorical breadth of the concept of character as she does, but to look instead at the "arabesque patterning, metaphorical chains and networks of analogy" (xxiii) that represent a fully-realized coherence between language and moral philosophy, most strikingly within the work of Adam Smith. We would now recognize that Smith's body of work taken as a whole contains an expansive and deeply networked moral theory most clearly delineated within the Scottish Enlightenment's stunning understanding of language and its place in the moral economy of the social human person. In other words, scholars now recognize that Smith's work in Theory of Moral Sentiments developed alongside his 
work in rhetoric and language theory. ${ }^{1}$ Smith's work stands at the forefront of a more widely encompassing rhetorical vision; even so, the present state of scholarship contains the need for a literary-minded critique of his rhetorical and moral thinking. It is Smith's "peculiar power of perception" - the moral sense - that must be accounted for within aesthetic judgment in order to create compelling grounds for a new literary critique.

In this spirit, the dissertation is an inquiry into the ways rhetoric and literature were coherently theorized in Enlightenment Scotland to articulate the nature of language and its inherent and complex relationship to the human mind and its faculties. As an overarching program of research, the three chapters contained in this dissertation are distinct and free-standing studies in eighteenth-century Scottish rhetorical theory, examining through three different lenses the multiple and sometimes contradictory legacies of this important body of work on language pedagogy, philosophy of mind and language, and political theory. All three chapters taken together conscientiously seek to build a comprehensive interdisciplinary understanding of this area of the Scottish Enlightenment in order to contribute to a stable platform from which, in future work, I can critically approach the new aesthetic of Enlightenment vernacular poetry. Scottish Enlightenment thinkers produced not only seminal works of rhetoric and philosophy, but also a new literary aesthetic, and practices of reading and writing whose influences still reverberate within our modern academic disciplines. This same movement also created the modern academic

\footnotetext{
${ }^{1}$ See Jerry Evensky, Adam Smith's Moral Philosophy (Cambridge, 2005), Stephen McKenna, Adam Smith: Rhetoric of Propriety (Albany: State University of New York, 2006), Nicholas Phillipson, Adam Smith (Yale: Yale University Press, 2011) for examples of this more holistic approach to Smith studies.
} 
disciplines as discrete fields, and much of the intellectual work contained herein is a re-conceptualization of the disciplinary unity required to approach eighteenth-century rhetoric and literature with the degree of interconnectedness and interdisciplinary cohesion within which it was formed. Scottish rhetoric cogently theorizes the nature of language and its constitutive relationship to the human faculties. Most particularly, Scottish Enlightenment rhetoric postulates the connection between moral, social, and language practices: an understanding of the moral properties of language is essential to forming a critique of Scottish Enlightenment literary productions that apprehends this basis of their innovative aesthetic. The Scottish belles lettres tradition most frequently characterizes the relationship between eighteenth-century Scottish moral sentiments theory and language theory. But as these chapters demonstrate, often the historical narrative of belles lettres contains retrospective mischaracterization of both "taste" and the moral sentiments theory. What has lingered in the word belles lettres is the more nineteenth-century sense of moral and social obligation contained within the reading practices of belles lettres, what has been made explicit is more twentieth-century argument connecting belletristic language practices, social mobility, and elitism. Eighteenth-century rhetoric has a long-standing critical connection to belles lettres, and this is a perfectly appropriate starting point to a conversation about literature and rhetoric in the eighteenth century. Yet the conversation must extend past this, and not as much work has been done to examine the critical philosophical and theoretical configurations between literary productions, rhetoric, and belles lettres. The legacy of belles lettres extending into the study of nineteenth-century literature is welldocumented also, but like the other disciplinary areas addressed in the works included 
here, the eighteenth-century roots are commonly presented as points of departure for nineteenth- and twentieth-century thinkers, and in retrospective critique. In contrast, this dissertation presents material that looks at these overlapping areas of rhetoric, literature, belles lettres and moral theory from the more productive perspective of Scottish Enlightenment philosophy of language and mind.

The order of the manuscripts is not chronological, as I have placed the most recent publication first, for the reason that the "Introduction" I wrote to the Scottish Philosophy of Rhetoric (2014) offers a comprehensive introduction to the period and my work on it. All three of the manuscripts consist of previously published work in their published formats.

\section{Summaries:}

The first chapter of this dissertation is the "Introduction" to Scottish Philosophy of Rhetoric (ed. Rosaleen Keefe, Edinburgh: Imprint Academic Press, 2013). It is included here at the outset because it provides a concise introduction to the major figures, their works, and themes of Scottish eighteenth-century rhetoric. The central argument in this introduction is that the rhetorical theories of Francis Hutcheson, Alexander Gerard, Henry Home, Lord Kames, Thomas Reid, George Campbell, Hugh Blair, and somewhat later, Alexander Bain, are crucial components of the Scottish philosophical canon. Along with a brief synopsis of rhetoric and logic in eighteenth-century Scotland, this chapter describes six identifiable themes within the Scottish rhetorical tradition: the orientation of the rhetor towards the good, rhetoric as a moral art, the theorization of taste, the turn towards literary criticism, rhetoric as a means of personal improvement, and the advocacy of a simple, direct style. A final 
section of this chapter summarizes the contents of the readings from the original eighteenth-century texts that I chose for inclusion in the volume. This introduction provides a succinct but thorough introduction to Scottish Enlightenment thinking. Like the other publications included in this dissertation, it provides evidence for, as one reviewer puts it, the "substantive moral, epistemological, and civic purposes" within the Scottish rhetorical tradition.

Chapter 2 consists of "The Legacy of Petrus Ramus in U.S. Composition: Realism, Scottish Common Sense, and Peircean Pragmatic Method," a chapter which was included in an edited scholarly book entitled Ramus, Pedagogy, and the Liberal Arts: Ramism in Britain and the Wider World (Ed. Steven Reid and Emma A. Wilson. London: Ashgate Press, 2011). This chapter examines the complicated legacy of the supposed separation of rhetoric and dialectic instituted by the work of Petrus Ramus in the sixteenth century, and its continuance in the work of the Scottish rhetoricians of the eighteenth century. By making a case for the multiple trajectories of Scottish Enlightenment rhetoric via its connection to the work of the nineteenth-century American philosopher Charles Sanders Peirce, this chapter challenges the accepted logic of the history of composition studies with regards to Ramism and Scottish rhetoric. The belles-lettres tradition, as it came into American university curriculums via the texts of Hugh Blair, has been credited with sponsoring the practice of criticism, and moreover, positivistic, realist criticism, as the primary approach to reading and writing in the classroom. This approach occurred within the pedagogy of reading (as it became a discipline of literary criticism) and also for writing (as it became the subdiscipline of composition). By the twentieth century, progressive educators had 
roundly rejected the pedagogical products of bellestric literary practices, namely "current-traditional" rhetorical teaching and positivistic literary criticism. As a part of this rejection, it was argued that "current-traditional" rhetoric $^{2}$ and positivist criticism seem to share the Ramistic separation of invention from rhetoric. Based on this shared separation, twentieth-century rhetorical history argues for the connection between Scottish rhetoric and Ramism, even though by the eighteenth-century Ramism as a movement was long-since forgotten in Scottish universities. As an alternative to this narrative, this chapter points out that the key rhetorical concept of "taste" within the work of Blair and the Scottish rhetoricians is not a function of the dyadic relationship between logic and language. It is rather a mediating faculty between the senses, imagination, and reason. The Scottish theory of "taste," is, in fact, a close philosophical relative to C.S. Peirce's semiotic theory. Peirce acknowledged his debt to Scottish common-sense Enlightenment thinkers, and this chapter examines Peircean semiotic theory's use of Scottish rhetoric, thereby offering a re-reading of the ideological linkages between Ramism, Scottish rhetoric, and eighteenth-century language practices. Both the rhetorical theory of "taste" within language-use and Peirce's theory of "semiosis" within the structures of signification employ methods that are remarkably similar in function and outcome. Both methods unite logic and rhetoric within a flexible method that encompasses personal and social invention, multiple levels of mediation of perception, and also a real world within which they create. A careful analysis of the overlaps between these two methods, in addition to the historical and philosophical connections between Peirce and Thomas Reid

${ }^{2}$ See Manuscript Two, pp 51-53, for a full discussion of this term. 
provides good grounds to re-evaluate the ideological connection between Ramism, Scottish Common Sense's theorization of taste, and American composition's “currenttraditional" rhetoric.

The final chapter of this dissertation is an article that was awarded the George Elder Davies Prize for best graduate student paper at the Princeton Theological Seminary Bicentenary Celebration Conference at the Center for the Study of Scottish Philosophy and was subsequently published in the Journal of Scottish Philosophy (Vol.11, 2013, Issue 2: 213-228). Entitled “Common-Sense Rhetorical Theory, Pluralism, and Natural Law Theory," this article offers a close examination of the philosophy of language in Campbell's Philosophy of Rhetoric as well as Blair's concept of taste and Alexander Bain's theory of the "doubleness of language"3 in order to articulate (more fully here than in the previous chapters) the ways in which Scottish rhetoric conceives the epistemic ${ }^{4}$ functions of language. This chapter argues that Scottish rhetoric does not see rhetorical knowledge as permanent and stable but rather as a conditional exchange between the rhetor and her audience, which is one of the arts constitutive to human nature itself. Because of the inherent sociability of all of the human faculties of language, from which reason is derived, moral consensus is a key area of concern. As all of the higher faculties of man operate contextually, education and civil institutions take on a moral function as well. And finally, on account of the praxis of rhetorical personal and civic taste, this chapter suggests that Scottish

\footnotetext{
${ }^{3}$ Bain [1877] (2005) English Composition and Rhetoric, 176.

${ }^{4}$ By this term, I mean the functions of language that actually bring into being new understanding, practices, knowledge, or ways of knowing. This may be in contrasted to language's mimetic function.
} 
Enlightenment rhetoric offers a tool necessary for the continuance of a pluralistic society. For pluralism to function there must be a means of achieving conditional forms of moral consensus, and the Scottish rhetors of the eighteenth century were deeply invested in meeting this need within their own Enlightenment milieu.

\section{Conclusion}

The Scottish Enlightenment discovered ways of theorizing language that are resonant in what are today widely divergent fields, from political theory to theories of cognition, and that Scottish Enlightenment thinking offers a profoundly relevant understanding of the ethical and moral dimensions of language learning and language use. Eighteenth-century Scotland gives us an example of the kinds of development possible when the disciplines operate in an open and cooperative manner, united under the practice of the most ancient discipline, rhetoric, and a most fundamental inquiry, language-use. In our own modern iterations of deliberative democratic discourse, we would do well to look again at this moment of rhetorical flourishing. 


\section{TABLE OF CONTENTS}

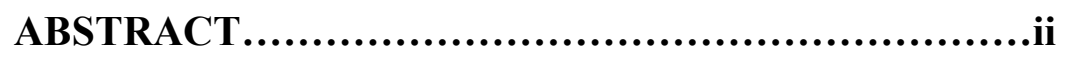

ACKNOWLEDGEMENTS............................iii

PREFACE...............................................v

TABLE OF CONTENTS....................................xiii

MANUSCRIPT ONE..........................................1

"Introduction" to Scottish Philosophy of Rhetoric: Selected Philosophical Writings.

MANUSCRIPT TWO...........................................30

“The Legacy of Petrus Ramus in U.S. Composition: Realism, Scottish Common Sense, and Peircean Pragmatic Method"

MANUSCRIPT THREE..........................................61

"Common Sense Rhetorical Theory, Pluralism, and Protestant Natural Law." 


\section{MANUSCRIPT ONE}

"Introduction" to Scottish Philosophy of Rhetoric: Selected Philosophical Writings. Edited and with an introduction by Rosaleen Keefe. Library of Scottish Philosophy. Imprint Academic Press, 2014. ISBN 9781845405618.

(C) Rosaleen Keefe, 2014

The moral rights of the author have been asserted. No part of this publication may be reproduced in any form without permission, except for quotation of brief passages in criticism and discussion.

Published in the U.K by Imprint Academic, P.O. Box 200, Exeter EX5 5YX, UK.

Distributed in the U.S.A. by Ingram Book Company, One Ingram Blvd., La Vergne, TN 37086, USA. A CIP catalogue of this book is available from the British Library and the US Library of Congress.

www.imprint-academic.com/losp 


\begin{abstract}
This manuscript consists of the entire "Introduction" to the Scottish Philosophy of Rhetoric: Selected Philosophical Writings (2014). This text provides a succinct overview of the Scottish rhetorical tradition within the context of the Scottish philosophical tradition, focusing on the eighteenth-century Enlightenment period. It outlines six identifiable themes in Scottish rhetoric. It outlines six identifiable themes in Scottish rhetoric: the rhetor's necessary orientation to the good, rhetoric as a moral art, the exploration of taste, the foundations of literary criticism, rhetoric as a means of personal improvement, and advocacy of simple style are explained as contiguous with the larger philosophical contexts of understanding mind, language, and moral sense. Finally, this manuscript describes the Scottish writers and the selections of their work chosen by the editor for inclusion in the volume.
\end{abstract}




\section{Preface}

The following manuscript was written in 2013 after I was asked to prepare and edit a volume on Scottish rhetoric for the Library of Scottish Philosophy, and it was commissioned by the Center for the Study for Scottish Philosophy at Princeton Theological Seminary. My volume is number 16 in the series. The series is meant to help expand and make accessible more of the Scottish philosophical tradition than just the major writings of the central figures of the Scottish Enlightenment. The Scottish Philosophy of Rhetoric is unique in that it offers readings that connect the philosophical tradition with the rhetorical textbooks produced under its influence. Included in this dissertation is the short "Introduction" to the volume.

The eighteenth-century primary texts to which this manuscript refers are as follows, in alphabetical order by author:

Bain, Alexander. English Composition and Rhetoric. London: Longmans and Green, 1877.

Blair, Hugh. Lectures on Rhetoric and Belles Lettres. Second edition, corrected. London: T. Cadell, W. Strahane; Edinburgh: W.Creech. 1785.

Campbell, George. The Philosophy of Rhetoric. Edinburgh: Archibald Constable \& co, 1816.

Gerard, Alexander. Essay on Taste. Second Edition. Edinburgh: A. Millar, 1758.

Homes, Henry Lord Kames. Elements of Criticism. Fourth Edition. Edinburgh: Kincaid and Bell, 1769.

Hutcheson, Francis. Inquiry into the Original of Our Ideas Of Beauty and Virtue.London: J. Darby of Bartholomew Close, 1725. 
. System of Moral Philosophy in Three Parts. Glasgow: R. and A. Foulis, 1755.

Smith, Adam. Lectures on Rhetoric and Belles Lettres (Delivered at the University of Glasgow by Adam Smith. Reported by a Student in 1762-3). Edited and with an Introduction and notes by John M. Lothian. Edinburgh and London: Thomas Nelson and Sons, 1963.

Reid, Thomas. Essays on the Intellectual and Active Powers of Man, Dublin: L. White, 1786.

. Inquiry into the Human Mind upon the Principles of Common Sense, $4^{\text {th }}$ Edition. London: Cadell, Edinburgh: J. Bell and W. Creech, 1785. 


\section{TEXT}

\section{Scottish Rhetoric and Scottish Philosophy}

The Scottish contribution to the creation of modern Western institutions is one of the most surprising chapters in the history of modernity. It is counterintuitive to suppose that such a small and low profile country should be the source of philosophical innovations that forged the conceptual foundations of political, social, psychological, educational, and economic systems still functioning today. It may also seem counter-intuitive to regard the oft-forgotten discipline of rhetoric as central to the philosophical practice that produced these foundations. So in imagining a volume on the Scottish Philosophy of Rhetoric, it may appear overambitious to link the Scottish philosophical tradition to the Scottish rhetorical texts so closely, especially since the Enlightenment rhetorical tradition, particularly when viewed from the perspective of writing and reading pedagogy, is often seen as simply an obtuse and dated addendum to the main philosophical tradition.

On the other hand, within rhetorical history, the eighteenth century is widely regarded as the central nexus of the development of many modern conversations about language, language-learning, social and cognitive development through language, semantics, linguistics, discourse theory, and civic participation. Further, any consideration of eighteenth- and nineteenth-century rhetoric must focus on the contributions of Scottish writers and professors such as George Campbell and Hugh Blair. The selections in this volume have been chosen in order to show readers both why the Scottish contributions to rhetoric are important for those conversations, and also how essential their place is in the Scottish philosophical tradition. 
To whom amongst the many eminent Scottish Enlightenment thinkers should we look first for the key texts of Scottish rhetoric? Rhetoric, though a subject of widespread interest at that time, is hard to confine within any one discipline, as indeed it continues to be. Linda Ferreira-Buckley, describing the broad state of eighteenth-century rhetoric, points out that "then, as now, "rhetoric" is an expansive phenomenon and a slippery term. Understanding the eighteenth-century requires looking beyond disciplinary boundaries that may have come to seem natural' ${ }^{5}$ The arguments regarding aesthetics, epistemology, and the ontology of perception, philosophy of mind, and logic put forward by Francis Hutcheson, Alexander Gerard, Lord Kames, and Thomas Reid in response to the innovations in philosophy, logic, and method that were made by Bacon, Newton, Locke, and Berkeley are now fixed parts of the philosophical context. But while the Scottish philosophers themselves considered rhetorical inquiry and teaching central to their own work, their ideas on rhetoric and language were developed even further by their students, Campbell and Blair (and several decades later, Alexander Bain), all of whom wrote rhetorical theory and textbooks that influenced generations of language learners on several continents. Often, these texts are taken to represent only the Scottish rhetorical tradition, but they have an equally important role in the philosophy of language.

The selections in this volume comprise a unique introduction to Scottish rhetorical innovations that have generally been overlooked in studies of the

${ }^{5}$ Ferriera-Buckley, Linda, 'The Eighteenth Century', in The Present State of Scholarship in the History of Rhetoric, Columbia: University of Missouri Press, 2010. 
philosophical tradition, while at the same time being used to oversimplify the rhetorical tradition. This volume is the first of its kind to choose texts in such a way as to demonstrate, and not simply refer to, these essential connections between Scottish philosophy and Scottish rhetoric. Organized loosely by bio- graphic and bibliographic succession, the aim is to exhibit the variety and vigour of Scottish rhetorical thinking, while placing it within the broader conceptual structure developed and articulated by George Campbell and Hugh Blair. It requires some flexibility on the part of the reader to examine philosophical texts for their rhetorical theory, and at the same time read pedagogical texts for their underlying philosophy of language. Only in this way, however, do we arrive at a more complete picture of Scottish rhetoric, as a vibrant and resonant body of rhetorical theory and practice. It is my hope that a reader from any discipline, not only those interested in Scottish philosophy or rhetorical theory, will gain a new comprehension of the centrality of the Scottish rhetorical tradition to these topics.

\section{Rhetoric and Logic in Eighteenth-Century Scotland}

In the classical tradition, rhetoric is one of the three cornerstones of a basic education in the liberal arts, the trivium, which consisted of logic, rhetoric, and grammar. The study of rhetoric, defined by Aristotle as the 'ability to see, in each particular case, the means of persuasion', ${ }^{6}$ was since ancient times considered a first order in education; it

\footnotetext{
${ }^{6}$ Aristotle, On Rhetoric, translated by George Kennedy, Oxford: Oxford University Press, 1991, 2.1, p. 36. Kennedy notes that Aristotle defines rhetoric into the genus of dynamis, or 'potentiality', indicating that rhetoric is the not the product of speech or
} 
is easy to see how along with grammar, the basic means for forming intelligible units of speech, and logic, the art of constructing rationally valid arguments, these three together create a fitting foundation to intellectual inquiry. All of the authors included in this volume would have had a thorough background in the history and practice of rhetoric and logic. The relationship of logic to rhetoric is of particular importance to the development of what Wilbur Samuel Howell, in his seminal histories of eighteenth-century logic and rhetoric, ${ }^{7}$ termed the 'new rhetoric' of Enlightenment thinkers, and it is also crucial to understanding the rhetorical innovations of the Scottish Enlightenment.

Logic had undergone a transformation since the works of Francis Bacon, who persuasively condemned the classical Aristotelian syllogism as an insufficient tool for genuine scientific inquiry. Bacon argued that science required a logical form that allowed for observation and inquiry, and that syllogism and the art of deduction could only form arguments from what is, essentially, already known. A new logic of induction was necessary for the new scientific method. This inductive method relies not on a priori knowledge, but rather on observation of particulars, and probabilities of

writing, it is the 'art of "seeing" how persuasion may be effected' (p. 36, footnote 34). This is an important distinction, relative to the Scottish philosophy of rhetoric as well. The art of rhetoric must not be confused with the products of rhetorical arts.

${ }^{7}$ Howell, Wilbur Samuel, Eighteenth Century British Logic and Rhetoric, Princeton: Princeton University Press, 1971; and Logic and Rhetoric in England, 15001700,Princeton: Princeton University Press, 1956. 
generalities. The discipline of logic, therefore, needed to be reformed. Now, Alexander Broadie argues that 'in the forefront of this discussion on logic in the mid-eighteenth century' and 'pressing for debate toward further modernization of the discipline ${ }^{8}$ was none other than Thomas Reid. Reid is much better known for his development of Scottish Common Sense philosophy, dealing with the more abstract branches of epistemology and philosophy of mind, but it is important to note that, like many of the thinkers included here for their important work in rhetorical theory, he was as wellversed in science and mathematics as in philosophical inquiry. This is essential to understanding the motivation for the rhetorical innovations he, like others, advocated. In fact, the relation of logic to rhetoric and the concern with science is essential to understanding the particularly Scottish Enlightenment crafting of the 'science of man': that is, the application of the new scientific method to the study of the human mind and its products. First amongst the particular, observable phenomena produced by the mind is, of course, language. And here we can see, from a methodological point of view, the need for and keen interest in a new rhetorical theory.

Rhetoric in the classical tradition was concerned primarily with persuasion, but it became a key method of inquiry in the new science of man. It was seen as a tool for analysing the faculties of the mind that are observed in the processes of knowing, or coming to a belief or understanding. The Scottish rhetors were equally concerned with the implications of this knowledge; that is, with the formation of taste, of civic and

${ }^{8}$ Broadie, Thomas Reid on Logic, Rhetoric, and the Fine Arts: Papers on the Culture of the Mind, University Park, PA: Penn State University Press, 2004, p. xxiv. 
personal virtue, and the creation of the bonds of sympathy and mutual understanding that form the basis of civil society. Their rhetorical theory is closely tied to a concordant philosophy of language, of aesthetics and the fine arts, and also of political philosophy. Among the thinkers included in this volume, many are indeed better known for their work in these allied fields: Francis Hutcheson is primarily considered a moral philosopher; Lord Kames was a leading legal thinker and historian who later turned to aesthetic inquiry; Alexander Gerard is known for his work on taste and genius; Adam Smith is primarily identified with economics and political theory; Thomas Reid is most notable as a philosopher of mind. Only George Campbell and Hugh Blair are identified as rhetoricians, although, like the others, their rhetorical theory was a practical extension of a polymathic range of interests. Two other Scottish thinkers relevant to rhetorical history must also be noted, though with explanation, however, one for his inclusion in this list of rhetoricians, and one for his exclusion. Alexander Bain, living and working as he did almost a full generation after the Enlightenment, is an essential thinker in understanding how Scottish rhetoric was transformed in the nineteenth century and beyond. While it owes much to the Scottish philosophy in which he himself was educated, Bain's work on rhetoric and his rhetorical textbooks reflect what happened when much later, largely experimental work on cognition and psychology met with Common Sense philosophy of language. Much of what is today considered to be the legacy of Scottish rhetoric owes more to the pedagogical trends advanced by Alexander Bain than to the more philosophical works of earlier Scottish rhetoric. Bain's influential writings helped develop the empirical tendencies of faculty psychology into a more positivistic perspective on 
language use. The most striking exclusion from this volume is David Hume.

Hume's work on the philosophy of mind and understanding is ever present in the work of his Scottish contemporaries, but his only direct writing on rhetoric, 'On Eloquence', though ostensibly dealing with the rhetorical art of oratory, is contradictory and notoriously difficult to interpret as rhetorical theory, and not easily included within the more identifiable concerns of Scottish rhetoric. Still, the exclusion of Hume from this volume should not be understood as a judgment on his relevance to Scottish rhetoric, only that his writings on rhetoric are primarily of interest to a more specialized audience. ${ }^{9}$

\section{Themes in Scottish Rhetoric}

Several hallmarks of Scottish rhetoric need to be highlighted, so that the reader may critique and compare their development in the readings that follow. The list is neither exhaustive nor definitive, but six themes - the rhetor's necessary orientation to the good, rhetoric as a moral art, the exploration of taste, the foundations of literary criticism, rhetoric as a means of personal improvement, and advocacy of simple style - provide a good guide to the rich and innovative Scottish contribution to an

\footnotetext{
${ }^{9} \mathrm{~A}$ word might be said here also of the exclusion of John Witherspoon and his contemporary Scots in America. While Witherspoon was born and educated in Scotland, and is thus a product of the Scottish rhetorical tradition, his own rhetorical writings were written in and for the American context. For this reason they are better regarded as founding documents of the American rhetorical tradition.
} 
ancient and complex discipline.

The first consistent theme found in Scottish rhetorical theory is that effective rhetoric is intimately connected to the rhetor's own orientation to the true and good. Persuasion, and the creation of what is moving and pleasing to properly formed taste, is possible only when it is generated by one whose own moral and intellectual tastes have been properly formed. This follows Ciceronian rhetoric, along with Quintilian's teaching that rhetoric is the 'good man speaking well'. In addition, however, it reflects the new territory that rhetoric occupies in its relation to the scientific method and experiential knowing. Scientific thinking is also concerned with what is true, even if its observations and the general laws they generate are probable truths only. Rhetorical skill is thus tied to a posteriori inquiry - the audience judges not only by language and skilled argument, but by what they observe through their own experiences of the speaker. Effective language touches the "chord, which when struck, the human heart is made to answer' (Blair, Reading XVII). This shared, universal faculty registers pleasure at what is true, consistent, virtuous, and laudable. Whether we are using rhetoric or listening to it, good rhetoric relies on all the faculties, internal and external, to judge the product.

The second, possibly most important, theme of Scottish rhetoric - the affirmation of rhetoric as a moral art—is closely tied to the first. Language is the first foundation of civic life, the establishment of basic contracts, conventions, and habits all of which profoundly shape social intercourse and the foundations of civility, and influence moral action and formation. Language use activates our internal sense and for this reason the Scottish philosophers were keenly interested in investigating both 
childhood formation and the anthropological evidence of language development. Our internal inclinations and habits, they argued, are formed by internal and external patterns of understanding and approbation. Language is the tool by which we learn to distinguish, discern, and evaluate. Scottish philosophy thus conceives of rhetoric as the interface between the new science of man and its moral, ethical, and aesthetic implications.

That is why close attention was paid to what are now the most widely identified features of Scottish rhetoric, namely 'taste' and the foundations of criticism. Because language operates by social convention, the formation of those conventions is of great importance to civic life. Thus, how one's taste is fashioned-whether or not it functions properly to discern what is good and beautiful and derive pleasure from itis a prerequisite not only of personal moral life and character, but of public ethics and standards of civility. For George Campbell, correct usage of language is what is 'reputable, national and present', and it is collectively exercised taste that generates these criteria. Like the ancients, the Scottish rhetoricians viewed rhetoric, properly conceived and developed, as the first condition to liberty; civil discourse is the condition of political freedom. The exercise of polite and civil taste in language use was consequently of great concern, so that its development became increasingly important as the new rhetoric took deeper hold in education. In the excerpts that follow, different authors treat the concept of taste differently. Alexander Gerard's theory is concerned to outline mental and sensory association and its moral implications, while Kames straightforwardly gives examples and descriptions of good (and poor) taste. Blair's concept of taste is deeply philosophical, though his 
pedagogical legacy has given him the reputation of an arbiter of eighteenth-century tastes rather than an aesthetic philosopher of language. It was Adam Smith who delivered the stunning first public lectures on Rhetoric and Belles lettres in Edinburgh in the late 1740s, but Hugh Blair who held the first academic chair with this title, and the development of the modern English literature department in which the study and critique of texts is a separate academic discipline has been dated to his appointment to it in 1762. 'Belles lettres' - the appreciation and criticism of texts for their aesthetic value — had already been developed to some degree by the French academy. Smith was on the vanguard of bringing this new trend to Scotland, having studied at Oxford, where he read extensively in rhetoric, literatures of several languages, and the French belles lettres. Classical rhetoric had been limited to argument and persuasion, but as it responded to the development of logic it became more than the linguistic 'dressing' for argument. It made artistic expression in language its territory, and expanded its attention to other kinds of texts. Rhetoric was no longer simply an art of persuasion that made appeals to logos, ethos, and pathos. It now was the art of creating, and criticizing, language in all its written and oral forms. If the advancement of taste may be considered the third theme, the expansion of rhetoric to all things now considered literary may be counted the fourth.

An impulse to improvement constitutes the fifth notable theme in Scottish rhetoric. Its development as a discipline for the cultivation of taste and criticism was clearly a response to the new philosophy of mind, and its effect on logic and scientific method. But it was the political and social environment of Scotland in the eighteenth century that pushed it from the academy to the cultural centre stage. Scotland's 
growing political and economic freedom, together with an already well-functioning educational system, facilitated widespread interest in self-improvement for the purposes of personal advancement and civic participation. National improvement was also part of the agenda, because the 1707 Act of Union with England had made the Scots intensely concerned with national and cultural identity and historicity. Rhetoric had a two-fold part to play in this desire for improvement. First, as the discipline of the cultivation of personal taste, it was an aid to personal growth in the polite and civic arts, which in turn was expected to cultivate moral sensitivity. Secondly was a more pragmatic concern with language use as social currency favoured it. Smith was chosen for his public lectures not only for his knowledge of rhetoric and belles lettres and his skill as a teacher, but also for the 'correctness' of his speech and pronunciation. His lectures were considered edifying for his mastery of 'proper' English as well as their content. Though somewhat at odds with the rising interest in Scots Gaelic and national literature, the desire for greater social currency in the English political and economic system led to the avoidance of Scotticisms, and this particular kind of rhetorical 'improvement' was one of the sources of rhetoric's popularity, while the sixth, the advocacy of simple and direct style, is immediately related to it. Rhetoric as it was practised from Cicero on had tended to emphasize specific arrangement and ornate, carefully crafted style, so much so that rhetoric itself had become synonymous with lavish use of figures, tropes, and flowery impenetrability. In addition to meeting the needs of the altered political and economic circumstances of the eighteenth century, the new rhetoric promoted a plain and simple style in response to the changing religious attitudes. The need was for religious and civil leaders to preach and discourse 
effectively to wider and more diverse audiences. Those who taught rhetoric at the universities in Scotland knew that many of their students intended to enter the Church or the Law, and that the old style of rhetorical ornamentation was not suited to congregations and juries who no longer came from social and educational stratum. Howell noted that the earlier rhetoric had followed a 'ceremonial pattern', which was

found by successive generations to be perfectly suited to their tastes in a culture dominated by splendid rituals and by elaborate political pageantries of imperial, royal, and aristocratic rule. But the Reformation and the Counter-Reformation on the one hand, and the rise of the parliamentary government, on the other, tended to expose the uselessness of a merely ceremonial rhetoric and to create a thirst for the religious and political discourses that in content would be fully relevant to the facts of the given situation and in form would be simple and easy to grasp. ${ }^{10}$

In no place would both of these factors be more strongly at play than in Scotland, and nowhere therefore was the plain style more universally regarded.

\section{The Extracts}

Most of the authors included here were contemporaries, and many were intimate friends or close acquaintances. Francis Hutcheson, who opens this selection, along with Henry Home, Lord Kames, Alexander Gerard, Thomas Reid, and to a lesser extent Adam Smith, have not traditionally been included among rhetoricians. Hutcheson and Reid are more typically read as philosophers and for their wide influence on the Scottish school. For both of these authors, I have selected texts from

${ }^{10}$ Howell, p. 446. 
their philosophical works that demonstrate the bearing philosophy of mind and philosophy of language have in understanding the rhetorical theory that developed under their influence. Hutcheson especially was in many ways a radical thinker. He succeeded Gershom Carmichael at the University of Glasgow, and was later succeeded by Adam Smith and Thomas Reid. He is therefore of the generation immediately prior to the rest of the authors (with the exception of Alexander Bain), and was an important influence on the philosophical milieu in which they were all educated. In his Inquiry into the Original of Our Ideas Of Beauty and Virtue (1725), he offers the outline of a moral and ethical system that can respond effectively to the egoistical challenge presented by Thomas Hobbes and Bernard Mandeville. Hutcheson argues that we have, in addition to the external senses, internal senses, among which is a moral sense, a sense of beauty, and a natural sociability. It is within the internal senses that language arises. Arts, including speech and poetry, are apprehended through our internal moral sense, by which we are stirred to participate in, and judge, the passions conveyed via the apprehension of 'universal goodness, tenderness, humanity, generosity... and our relish in beauty, order, and harmony' or their opposites. 'Upon this moral sense', Hutcheson tells us, 'is founded the power of the orator (Reading I). The audience needs no knowledge of rhetoric to be moved by it, and thus the ethical burden falls upon the rhetor. Hutcheson's fullest treatment of language is from his System of Moral Philosophy (1755) in which he devotes a chapter to 'Our Duty in the Use of Speech'. In this essay (Reading II) Hutcheson describes the moral sense as directed outward; we are interested in the good of others, we derive pleasure from what is good not just for ourselves but for all. At the essay's outset he summarizes 
language in the moral economy: 'As the power of communicating to each other our sentiments, desires, and intentions is one of the greatest blessings of the human species, so appropriately joined with our social feelings and affections, nature has also implanted a moral feeling in our hearts to regulate this power' (Reading II). It is from this articulation of the ethical nature of speech, and therefore of learning effective speech, that we see Scottish philosophy making language the central human faculty that mediates between the individual (in his senses and capacities), and society. Hutcheson is often noted for the fact that he was one of the first professors to teach in English, and consciously used his own rhetorical powers to stir an affective response to his teaching. On many of Scottish rhetoric's later themes and hallmarks, then, Hutcheson may be seen as both precursor and initiator.

Reid takes up these concerns from the perspective of moral philosophy. In the first extract I have chosen for this volume, he explains the basis of the principles of 'common sense', those that may be taken for granted in a philosophy of the mind. To do this, he relies on language not only as a kind of metaphor, but as itself an object for the application of the inductive method. 'The operations of our minds are denoted, in all languages, by active transitive verbs, which from their construction in grammar require not only a person and agent but likewise an object of the operation' (Reading $\mathbf{X})$. In the second selection from Reid's work, he considers the philosophical implications of saying that some of the powers of the mind are, by virtue of a 'real foundation in nature', 'social intellectual operations' (Reading XI). Language is the primary indicator of the nature and existence of these operations, as well the means of conducting them. In the third extract Reid relates rhetorical inquiry to semiotics, and 
explores rhetorical responsibility and the nature of contract in his discussion of 'artificial' signs (Reading XII). This distinction between those parts of language which are 'artificial' (exist by mutual agreement of signification), and those that are 'natural' (are inherently demonstrative of a communication), points to the close relationship that Reid perceives between the mind and the body. The philosophical grounding of much of the work of Scottish rhetoric is found within this conceptual framework - the reunion of the mind and body and the inherently social operation of reasoning and perception.

Alexander Gerard is best known for his work in educational reform and his writings on the defence and evidence for Christian doctrine. However, his works on taste and genius link the moral sense developed by Hutcheson and Reid with the rising discourse on the development of taste as a major component in the ethics of reading, writing, and speaking. His 'Essay on Taste' (1759) won a contest held by the Philosophical Club in Edinburgh, leading to publication and a wide audience. While Gerard is certainly not the sole influence on the treatment of taste in the rhetorical texts of Campbell and Blair, his articulation of the aesthetic of 'fitness' can surely be counted as an important connection between the ancients and the Scottish Enlightenment. 'Utility, or the fitness of things for answering their ends', is, for Gerard, the key to aesthetic practice, on two levels (Reading VIII). First, a work of aesthetic value is one in which invention is purposefully deployed in directing the 'choice, disposition, and embellishment of its parts'. Second, our ability to see fitness is a chief source of aesthetic pleasure, and therefore the first concern of criticism. Taste itself is a kind of sensation that supplies us with simple perceptions entirely 
distinguishable from all that we receive by external sense or reflection. Thus taste is not sensory, or a pure idea; rather, it exhibits a set of perceptions that result from direct perception. The fitness of associated perceptions to communicate their qualities rouses our sympathy, which 'enlivens' our ideas, converting them to passions and in turn affecting taste. The excerpt from his 'Essay on Taste' included here (Reading IX) describes the relation of taste and genius in specifically rhetorical terms. He incorporates into the eighteenth-century discussion on taste, genius, and imagination the classical link between invention and execution.

This concept of fitness is also developed by Lord Kames. Whereas Gerard is concerned with the epistemology of taste, and its implications for the moral and ethical, Kames's Elements of Criticism is concerned with its practical development. Kames's position within the rhetorical tradition has been contested, and his Elements have rarely been read as rhetorical theory. ${ }^{11}$ Yet the extract included here on 'Language of Passion' clearly conveys Kames's sense of eloquence and rhetoric as a fine art that can, and should, be criticized using faculties of judgment aligned both to universal standards of truth and to the properly functioning faculties of mind and emotion. Through copious literary illustrations, he gives examples of how to judge rhetorical usage for its fitness. A man of law by education and practice, Kames

${ }^{11}$ For a discussion of this, and ways of reading Kames's Elements of Criticism as a rhetoric of criticism, see Beth Innocenti Manolescu, 'Traditions of Rhetoric, Criticism, and Argument in Kames's "Elements of Criticism"”, Rhetoric Review, Vol. 22, No. 3 (2003), pp. 225-242. 
exhibits the impulse to teach the art of rhetorical criticism—-how to judge. For example, he describes, 'words, being intimately connected with the idea they represent, the greatest harmony is required between them. To express, for example, a humble sentiment in high sounding words is disagreeable by a discordant mixture of feelings' (Reading III). Kames is as much concerned with rhetorical practice (the judgment of works and art) as with philosophical theory (the principles of human nature that produce his principles of criticism). His particular account of criticism embodies many of the themes that are later developed by Hugh Blair, as well as constituting the clearest example of the type of positivist criticism later generations would roundly challenge.

It was Kames who commissioned the young Adam Smith to give public lectures upon the subject of Rhetoric and Belles lettres to the student body of Edinburgh, lectures he later gave to his students in Glasgow. Until the late 1950s, Smith's interest in rhetoric and literature was known, but nothing about its content. However, in the late 1950s, a set of student notes from his lectures in the academic year 1762-63 were found in an Aberdeenshire manor house by a John Maule Lothian, who transcribed and published them in 1963. While these lecture notes obviously cannot be taken as a wholly accurate account of Smith's thinking on rhetoric and belles lettres, they do give us enough intelligence to place Smith firmly at the vanguard of Scottish innovations in rhetorical theory. The selections included here offer insight into the many new directions in which Smith led his students' rhetorical understanding and usage. In them, the reader can see Smith's anthropological approach to language development, the subsequent national and regional emphasis on 
best use (see Reading IV), and his idea that proper style is not one absolute ideal which conforms perfectly to truth or beauty, but rather is that which is most fitted equally to rhetorical exigency and the character of the author (Reading $\mathbf{V})$. In this respect, Smith's rhetorical theory is consonant with his ethical emphasis on the particular and practical as opposed to the general and speculative, which is also intimately tied to his ideas about sympathy and sentiment. ${ }^{12}$

Reading VI provides some of Smith's most critical statements of the speculative bent to practical arts, and it is clear that he sees the practice of rhetoric as formative as well as indicative of character. Finally, in Reading VII, Smith ties his criticism of classical works and his theory of fittingness to both character and circumstance. He employs as the basis of his critical art an idea of historical, political, and economical contextualization that is radical both in its implications for the concept of rhetorical fittingness and because of its far- sighted vision of the nature of criticism.

George Campbell and Hugh Blair are the only writers in this volume whose reputations rest primarily on their contributions to eighteenth-century rhetorical theory, so that their work has become the standard exemplar of Scottish rhetoric. This is not entirely inaccurate. George Campbell's Philosophy of Rhetoric was written over the course of several decades (begun in the 1750s and published in 1776), during

${ }^{12}$ From Theory of Moral Sentiments: 'When we consider virtue or vice in an abstract and general manner, the qualities by which they excite these several sentiments seem in a great measure to disappear, and the sentiments themselves become less obvious' $(\mathrm{IV}, 2.2)$. 
which he presented parts of it as papers to the Philosophical Society in Aberdeen. In the process he had much time to think about its content with his friends and colleagues, including Thomas Reid, Alexander Gerard, and John Stewart, John Beattie, and Hugh Blair. ${ }^{13}$ Campbell's Philosophy of Rhetoric is a discerning and thorough distillation of Common Sense epistemology, Humean philosophy of mind, and Baconian method, as well as classical and contemporary rhetorical theory. Some have speculated that its completeness may be one of the reasons why none of his contemporaries (notably Smith) wrote a philosophy of rhetoric. ${ }^{14}$ Three of the most important chapters from Campbell's Rhetoric are excerpted here—-his own 'Introduction', in which he lays out his rhetorical system (Reading XIII); Chapter 1, 'The Nature and Foundations of Eloquence', in which he describes the faculties to which eloquence (a word here nearly interchangeable for 'rhetoric') applies (Reading XIV); and Chapter 4, 'Of the Relation which Eloquence bears to Logic and Grammar', which makes a careful argument about the relation of truth to persuasion, expanding the role of rhetoric from persuasion to consideration of 'not only... the subject, but also the speaker and hearers, and both the subject and the speaker for the sake of the hearers, or rather for the sake of the effect intended to be produced in them' (Reading XV). Blair explicitly takes up the social implications of this philosophical rhetoric in the 'Introduction' (Reading XVI) to his Lectures on Rhetoric and Belles lettres. His opening paragraph declares that the improvement of thought, human reasoning 'is not

\footnotetext{
${ }^{13}$ Blair was not a member of the Aberdeen Theological or Philosophical Societies, but he was a personal friend.

${ }^{14}$ Howell, p. 579.
} 
the effort or ability of one, so much as it is the result of the reason of many, arising from lights mutually communicated, in consequence of discourse and writing'. More than merely staking out the rhetorical arts as a primary human, intellectual, and moral concern, he makes rhetoric and the cultivation of critical faculties for the development and judgment of language the key academic discipline. Blair's assertion that clear speaking and writing produces clear thinking is one that has been largely ignored as an Enlightenment idea — and it remains one still hotly discussed in composition pedagogy. I have chosen his chapter on 'Taste' so that readers may see the continuity and differences of Blair's rather practical explanation of it versus the more conceptual discussions in the previous selections. Blair's shadow loomed large on the teaching of rhetoric in the era that followed his own, and it is an interesting question of pedagogy whether or not later interpreters and teachers of rhetoric emphasized the theoretical, productive, or interpretive rhetorical actions outlined in Blair's lengthy textbook.

One of the factors affecting later interpretations of rhetoric was the nineteenthcentury movement towards the empirical study of cognition and learning. The 'science of man' of the Scottish Enlightenment thinkers shifted from the 'science' of a proper epistemology, and philosophically- oriented psychology, to empirical, and often experimental, scientific inquiry into the physical workings of the mind and the emotions. At the forefront of this inquiry was Alexander Bain, founder of the journal Mind and an extremely influential academic educator and educational theorist. Bain's body of work is large, but for the purposes of demonstrating the pedagogical implications of the direction his work gave to Scottish rhetoric I have chosen a selection of one of his rhetorical textbooks. 
As noted by Ferriera-Buckley at the outset of this introduction, rhetoric is a slippery term. It must, by its nature, encompass theoretical inquiry, but this is always in tension with its equally natural orientation to practice. To give the contemporary reader a proper understanding of Scottish rhetoric in its eighteenth-century development and articulation, and of its inestimably important influence on both the American university and the twentieth-century evolution of academic disciplines in the humanities, the rhetorical theory must be read alongside the pedagogical practices it inspired. The Scottish philosophy of rhetoric is part of the larger philosophical tradition, and it must be acknowledged that the two bodies of work — the philosophies and the rhetorics - are not synonymous. Nor are the texts synonymous with their interpretations and uses, especially as they were taken up in university instruction overseas. The attention that the present writers give to the philosophical and moral importance of what is circumstantial and specific must be seen in critical juxtaposition to the kind of rhetorical improvement with which Scottish rhetoric is most often credited in modern histories (the speaking of polite and proper English, free of possibly misleading regionalisms). Blair's textbooks (which 'went through sixty-two editions, fifty-one abridgments and ten translations in the century after its publication'), ${ }^{15}$ and the legacy of Scottish rhetoric in general, has become in many ways coterminous with the self-improving impulse to use standard English on the part of Scottish and American students. James Berlin argues that when Blair's belles lettres tradition matured in American universities, uniting its attention to taste and literacy

15 Bizzell and Hertzberg, p. 657. 
with the scientific approach to persuasion and human faculties, it proved the ideal discipline for the "creation of the professional meritocracy consisting of an emerging middle class in the newly-elective nineteenth century American universities' ${ }^{16}$ Following him, the American Compositionists of this century have made it a point to note in their own histories of rhetoric and composition that 'the source of currenttraditional rhetoric ${ }^{17}$ is to be found in Campbell, Blair, and Whately'. ${ }^{18}$ This thesis has been readily accepted because of the widespread influence of Scottish Common Sense Realism in America at the time, which, it is assumed, provided appropriate grounds for positivist writing practices. However, this simple picture is complicated by the epistemological preference for local and specific language and its social and ethical ramifications as inductive evidence, the movement from classical languages to English vernacular that the Scottish rhetoricians promoted, and new works written in the Scottish dialects that they sponsored. ${ }^{19}$

These are just a few of the dimensions that a new inquiry into Scottish

${ }^{16}$ Berlin, p. 8.

${ }_{17}$ Current-traditional pedagogy is the turn from rhetorical instruction to 'composition' instruction. It teaches writing from the standpoint of an ideal final product: the essay composed strictly to answer its ends, with close attention to spelling and grammar. Current-traditional pedagogies teach a definitive 'right' writing final product, which is perfectly attuned to the needs of the audience (as explained in terms of cognitive or psychological science).

18 Ibid.

19 Blair personally sponsored the works of James McPherson and Robert Burns among others. 
philosophy and rhetoric in its eighteenth-century context might profitably explore. This would offer an enhanced historical understanding, as well as providing a novel way of approaching many of the current debates on the practice and politics of language use. The selections offered here uncover many rhetorical issues that are not only still relevant to today's academic and political climate, but still very much alive in discussion, scholarship, and query. 


\section{Works Cited}

Aristotle, On Rhetoric, translated by George Kennedy, Oxford: Oxford University Press, 1991.

Berlin, James, Rhetoric and Reality: Writing Instruction in American Colleges, 19001985, Carbondale: Southern Illinois University Press, 1987.

Bizzell, Patricia and Bruce Hertzberg, The Rhetorical Tradition, New York: Bedford, 1990.

Broadie, Alexander, Thomas Reid on Logic, Rhetoric, and the Fine Arts: Papers on the Culture of the Mind, University Park, PA: Penn State University Press, 2004.

Ferriera-Buckley, Linda, 'The Eighteenth Century', in The Present State of Scholarship in the History of Rhetoric, Columbia: University of Missouri Press, 2010.

Howell, Wilbur Samuel, Eighteenth-Century British Logic and Rhetoric, Princeton: Princeton University Press, 1971.

Lothian, John Maule, 'Introduction' to Lectures on Rhetoric and Belles lettres, Delivered in the University of Glasgow by Adam Smith, Reported by a Student in 1762-63, Edinburgh: Thomas Nelson and Sons Ltd., 1963. 


\section{Further Reading}

Agnew, Lois, 'The Civic Function of Taste: A Re-assessment of Hugh Blair's Rhetorical Theory', Rhetoric Society Quarterly, Vol. 28, No. 2 (1998), pp. 2536.

—, Outward, Visible Propriety: Stoic Philosophy and Eighteenth-Century British Rhetorics, Columbia: University of South Carolina Press, 2007.

Angus, Ian H., and Lenore Langsdorf, The Critical Turn: Rhetoric and Philosophy in Postmodern Discourse, Carbondale: Southern Illinois University Press, 1993.

Booth, Sherry, 'A Moment for Reform: Rhetoric and Literature at the University of Glasgow, 1862-1877', Rhetoric Review, 22.4 (Oct 2003), pp. 374-395.

Broadie, Alexander, A History of the Scottish Philosophy, Edinburgh: Edinburgh University Press (2009).

-, The Scottish Enlightenment: Historical Age of the Historical Nation, Cambridge: Cambridge University Press, 2007.

Craig, Cairns, Intending Scotland: Explorations in Scottish Culture Since the Enlightenment, Edinburgh: Edinburgh University Press, 2009.

—, The Modern Scottish Novel: Narrative and the National Imagination, Edinburgh: Edinburgh University Press, 1998.

Conley, Thomas, Rhetoric in the European Tradition, Chicago: University of Chicago Press, 1990.

Court, Franklin, Institutionalizing English Literature: The Culture and Politics of Literary Study, 1750-1990, Stanford: Stanford University Press, 1992.

Crawford, Robert, Devolving English Literature, Oxford: Clarendon Press, 1992. 
Dickie, George, The Century of Taste, Oxford: Oxford University Press, 2003.

Gaillett, Lynee Lewis, ed., Scottish Rhetoric and Its Influences, Mahwah, NJ: Hermagoras/Erlbaum, 1998.

Golden, James L., and Edward P.J. Corbett, The Rhetoric of Blair, Campbell, and Whately, Carbondale: Southern Illinois University Press, 1990.

Hanley, Ryan Patrick, Adam Smith and the Character of Virtue, Cambridge: Cambridge University Press, 2009.

Horner, Winifred Bryan, Nineteenth-Century Rhetoric: The American Connection, Carbondale: Southern Illinois University Press, 1993.

Kennedy, George A., Classical Rhetoric and its Christian and Secular Tradition, from Ancient to Modern Times, Chapel Hill: University of North Carolina Press, 1999.

King, Edward, 'From Logic to Rhetoric', Journal of Scottish Philosophy, 2.1 (2004), pp. $48-68$.

Lehman, William, Henry Home, Lord Kames, and the Scottish Enlightenment, The Hague: Martin Nijhoff, 1971.

Longaker, Mark Garret, ‘The Political Economy of Rhetorical Style: Hugh Blair's Response to the Civic-Commercial Dilemma', Quarterly Journal of Speech, 94.2 (May 2008), pp. 179-199.

MacDonald, A.A., 'The Sense of Place in Early Scottish Verse: Rhetoric and Reality', English Studies, 72.1 (February 1991), pp. 12-27.

MacDonald, Alistair, and Kees Dekker, eds., Rhetoric, Royalty and Reality: Essays in the Literary Culture of Medieval and Early Modern Scotland, Medievalia Groningana 
N.S.7, Leuven, Paris and Dudley, MA: Peeters, 2005.

Manolescu, Beth Innocenti, 'George Mackenzie on Scottish Rhetoric', Rhetorica, (Summer 2002), pp. 203-275.

—, 'Kames's Legal Career and Writings as Precedents for Elements of Criticism', Rhetorica, 23.3 (Summer 2005), pp. 239-259.

—, 'Traditions of Rhetoric, Criticism, and Argument in Kames' Elements of Criticism', Rhetoric Review, 22.3 (July 2003), pp. 225-244.

McKenna, Stephen J., Adam Smith: The Rhetoric of Propriety, Albany: State University of New York Press, 2006.

Mcllvanney, Liam, 'Hugh Blair, Robert Burns, and the Invention of Scottish Literature', Eighteenth Century Life, Vol. 29, No. 6.

Moran, Micheal, ed., Eighteenth Century British and American Rhetorics and Rhetoricians: Critical Studies and Sources, Westport: Greenwood Press, 1994.

Potkay, Adam, The Fate of Eloquence in the Age of Hume, Ithaca: Cornell University Press, 1994.

Short, Brian, 'Figurative Language and the Scottish New Rhetoric', Language Sciences, 22.3 (2000), pp. 251-264.

Warnick, Barbara, The Sixth Canon: Belletristic Rhetoric and Its French Antecedents, Columbia: University of South Carolina Press, 1993. 


\section{MANUSCRIPT TWO}

Keefe, Rosaleen Greene-Smith. "The Legacy of Petrus Ramus in U.S. Composition:

Realism, Scottish Common Sense, and Peircean Pragmatic Method" in Ramus,

Pedagogy, and the Liberal Arts. Edited by Emma Annette Wilson and Steven J. Reid.

Surrey, UK: Ashgate Publishing, 2011. ISBN 9780754667940.

(C) Editors and Contributors, 2011

All rights reserved. No part of this publication may be reproduced, stored in a retrieval system, or transmitted by any form or by any means electronic, mechanical, photocopying, recording or otherwise without the prior permission of the publisher.

Steven J. Reid and Emma Annette Wilson have asserted their rights under the Copyright, Designs and Patents Act, 1988, to be identified as the editors of this work.

Published in the U.K by Ashgate Publishing Limited, Wey Court Est, Union Court Road, Farnham, Surrey, GU9 7PT, England.

Published in the U.S.A. by Ashgate Publishing Company, Suite 420101 Cherry Street, Burlington, VT, USA. A CIP catalogue of this book is available from the British Library and the US Library of Congress.

$<$ www.routledge.com $>$ 


\begin{abstract}
The following manuscript examines the methodology of Ramus' separation of logic and dialectic within rhetorical pedagogy, and examines the multiple trajectories of these legacies within eighteenth-and nineteenth-century Scottish and American rhetoric and philosophy of language. Looking at the history of the belles lettres tradition, and its concomitant theorization of "taste," this manuscript complicates the accepted history of bellestric rhetoric as solely the eighteenth-century grounds of “current-traditional rhetoric." It offers a further development in the semiotic method of Charles Sanders Peirce, demonstrating that "taste," in its fully theorized place in Scottish rhetoric and moral sense theory, is a methodological predecessor to Peircean semiosis.
\end{abstract}




\section{Preface}

The following manuscript is a chapter from a volume of collected essays on the work and influence of Petrus Ramus (1515-1572), a sixteenth-century rhetorician, logician, and pedagogical innovator whose influence on early modern education was profound, if little understood or regarded. Written largely in response to the challenges put forward for Walter Ong, SJ., and Mordechai Feingold, the volume from which this chapter is extracted revisits the history of Ramus's influence across many subjects and in many diverse places, offering an interdisciplinary work of Ramism and Ramistic method much needed in current scholarship on the subject. The chapter here included has received widespread praise for bringing Ramism and the Ramistic legacy to bear on more modern academic and transatlantic pedagogy and rhetorical theory. "The Legacy of Petrus Ramus in U.S. Composition: Realism, Scottish Common Sense, and Peircean Pragmatic Method" addresses twentiethcentury century American rhetorical theory, its attributions of Ramistic method, and its roots in eighteenth-century rhetoric pedagogies responding to the Scottish Enlightenment rhetoric. It offers the methodological innovations of the nineteenthcentury philosopher Charles Sanders Peirce as an American counter-history of the Ramistic legacy. 


\section{TEXT}

\section{Introduction}

The relatively recent rise of the academic stature of the field of Composition and Rhetoric as a separate discipline in the United States has enabled a return of the popular definition of rhetoric to its Classical roots as the art ultimately of knowing and living in a mediated world. Encompassing within its field of study the vision of language and its uses as a field of both practical knowledge, pedagogy, and epistemology, in the past few decades modern rhetoricians and compositionists have turned back to evaluate the history of the field with regard to a self-conscious attempt to evaluate its current positions and future directions. This chapter attempts a critical look at the historical and philosophical trajectory of what is called 'current-traditional rhetoric', as it is ascribed as a pedagogical result, in part, of a Ramistic view of rhetoric: one which assumes a separation of dialectic from rhetoric, thus creating a dyadic relationship of logic to reality. Because current-traditional rhetoric removes invention from rhetoric and makes the creation of meaning a cold process of scientific logic, nearly every telling of its philosophical and historical path begins with the maverick moves of Petrus Ramus. Equally implicated in the development of "currenttraditional rhetoric" is the influence of the Scottish Common Sense rhetoricians, for like the Ramistic method, their works operate on a foundationally realist premise of language, and are largely held responsible for the development of literary and rhetorical criticism which in turn produced the major "current-traditional" 
pedagogies. However, another branch of realist method can also be seen as related to, and possibly derivative of, Scottish Common Sense rhetoric: Charles Sanders Peirce, the pioneer of semiotics, openly acknowledges his debt to 'the old Scots' in the development of his pragmatic method. This chapter, then, shall question the historical and intellectual relationship between Ramist, Scottish Common Sense, and Peircean method and rhetoric.

This chapter does not attempt to argue that these three pedagogical methods are synthetically and unquestionably related. There are between them many profound differences and original interpretations of the nature of language, logic, and knowledge. What this chapter does argue for, however, is a critical re-evaluation of the ideational genealogy between them. If we claim current-traditional rhetoric as a pedagogical end point of the Ramistic separation of dialectic and rhetoric, we must find some way to account for the radical divergences between this pedagogy and the Common Sense rhetoric from which it is assumed to derive, especially in light of the relation of Common Sensism to the origins of American pragmatism.

By suggesting that the popular narrative of ascribing a singular pedagogical outcome to the method of Ramus, or to Scottish Common Sense rhetoric, is inadequate, the call will hopefully be made to open ways of seeing and contextualising the work of these thinkers and their followers as more generative, complex and multiple than has been accounted for. In pointing out deficiencies in our understanding of the work of Ramus and the Common Sense rhetoricians, particularly by suggesting that American Pragmaticism shows traces of a Ramist lineage, this chapter aims to provide support for a re-evaluation of Ramus' contribution to the 
evolution of Composition studies in the U.S.. Indeed, it may well be that pointing out this deficiency provides a link towards the fuller evaluation of Ramus called for by Kees Meerhoff, who argues that:

'... far from being the start of an unfortunate evolution, the work of Ramus is rather the conclusion of a long humanist tradition during the course of which reading texts (a reading integrated more and more closely with a logic in its turn solidly attached to rhetoric) constituted the foundation both of creative invention and of the edifice of the human sciences'. ${ }^{20}$

Perhaps, if we include both current-traditional rhetoric and pragmatic rhetoric as branches of the Ramistic tree, we may find that his influence, like his method, took on dichotomous overtones among his later disciples.

\section{Current-Traditional Rhetoric: Background and History}

The field of Composition and Rhetoric has had multiple and altering historical frameworks, and the past two decades have seen an active re-engagement with the process of defining its history and ideological debts. Within this redefinition, however, there is one historical narrative that has achieved a cohesive stance. Largely unchanged and unchallenged is the idea that the belletristic tradition of reading and writing, derived from eighteenth-century Scottish Common Sense rhetoric, was taken and transformed in the United States into a pedagogy now widely known as 'current-

${ }^{20}$ Kees Meerhoff, 'Melanchthon, Latomus, Ramus: Teachers of Careful Reading', in Ton Hoenselaars and Arthur F Kinney (eds), Challenging Humanism: Essays in Honor of Dominic Baker Smith (Newark, 2005), p. 202. 
traditional rhetoric'. In 1959 Daniel Fogarty SJ published Roots for a New Rhetoric, coining this term, and made the argument that it was passed down to American universities from the works of the Scots Hugh Blair and George Campbell. ${ }^{21}$ The current-traditional approach was later defined by James Berlin as a pedagogy in which:

... truth in written discourse is conceived in exclusively empirical or rational terms, with persuasion relegated to oral discourse. The writing class is to focus on discourse that deals with the rational faculties: description and narration to be concerned with sense impression and imagination...exposition with setting forth the generalised ideas derived from sense impression and understanding, and argument with understanding leading to conviction. ${ }^{22}$

Within this approach rhetoric is a form of criticism, teaching the centrality of transmitting the rational as it communicates reality, with a final pedagogical concern for correctness in speech and writing. Because of its philosophical assumption that there is not only a real world but that it can be communicated, it is a fundamentally epistemologically positivistic form of teaching composition, entirely focused on error correction and universalised literary form. Current-traditional rhetoric, at its most

${ }^{21}$ Daniel Fogarty, Roots for a New Rhetoric (New York, 1959).

22 James A. Berlin, Rhetoric and Reality: Writing Instruction in American Colleges, 1900-1985 (Carbondale, Illinois, 1987), p. 8. 
practical, is a method of teaching reading and writing that concerns itself primarily with the mechanics of language use in a manner suited to fulfilling basic skills acquisition in required courses. James Berlin calls it the 'triumph of the scientific and technical world-view' in the writing classroom, which was created within the confines of newly developing elective American universities to address the needs of the emerging meritocracy of American society. ${ }^{23}$ As it emulates a scientifically positivist outlook on knowledge, it is also readily amenable to being methodised, with the result that generations of writing courses and textbooks systematically teach writing as a process of error correction and formulaic discourse representing differing modes of communicating reality (exposition, narration, description, etc.) in a methodologically logical manner.

The results of these teaching methods were widely criticised for making compositional teaching the drudge work of academia, for using rhetoric merely as a managerial tool of style and correctness, and for transforming reading and writing into instruments of hierarchical criticism (as good and bad writing can be judged using logical and transferable methods of correctness and conformity). As more sociallyepistemic views of reality and language became widespread, positivism lost its shine, and the American university faced a multicultural and multi-discoursed student body that was not adaptable to a method developed by and for an elite meritocracy. Current-traditional rhetoric, as a result, became the by-word for all that was wrong in

${ }^{23}$ James A. Berlin, Writing Instruction in Nineteenth Century American Colleges (Carbondale, Illinois, 1984), p. 62. 
writing instruction. When modern American compositionists became keen to uncover the roots of this pedagogy, the controversial works of Petrus Ramus soon emerged as the obvious starting point, with the works of the Scottish Common Sense school emerging as the transatlantic intermediary in this historical trajectory.

\section{Rhetoric, Ramus, and the Scottish Common-Sense School}

Current-traditional rhetoric is strongly linked, by both its historical predecessors and its pedagogical results, with the practice of objective criticism. As many literary historians have argued, literary criticism as we know it is a descendant of the movement of Belles lettres that originated in Scotland in the eighteenth century, also closely affiliated with the Scottish Common Sense School. ${ }^{24}$ Scottish Common Sense Philosophy is one whose eighteenth-century thinkers had as a first premise that the human mind can perceive truths that are self-evident, perceptions that are prior to reason, education or experience, and common to all persons. To a large extent the Scottish Common Sense position arose from Thomas Reid's (1710-1796) counter to the scepticism and idealism of the more dominant Enlightenment philosophers Hume

${ }^{24}$ See Franklin E. Court, Institutionalising English Literature: The Culture and Politics of Literary Study, 1750-1990 (Stanford, Connecticut, 1992); and Franklin E. Court, The Scottish Connection: The Rise of English Literary Study in Early America (Syracuse, New York, 2001); Robert Crawford, Devolving English Literature (Oxford/New York, 1992; repr. Edinburgh, 2000); and Robert Crawford (ed.), The Scottish Invention of English Literature (Cambridge, 1998 and 2008). 
and Berkeley. For Reid, the sceptical empiricist's claim that one can't infer the existence of anything else from the impressions and perceptions of one's own mind is utterly unsatisfactory: "upon this hypothesis, the whole universe about me, bodies and spirits, sun, moon, stars, and earth, friends and relations, all things without exception, which I had imagined to have a permanent existence whether I had imagined them or not, vanisheth at once." ${ }^{, 25}$ What he calls "common sense" falls not into the category of reason, but of "first principals," of which he argues that "the evidence of sense, the evidence of memory, and the evidence of the necessary relations of things, are all distinct and original kinds of evidence, equally grounded in our constitution." ${ }^{.6}$ Deeply realist, then, the notion of "common sense" formed a position that could account for a world that exists in common whether a human mind acknowledges it or not, but whose existence, principals, and concepts are accessible to all. This philosophy appealed greatly to those in the Scottish universities who were unwilling to accept the implications of scepticism, most particularly upon religious principals. What I am here calling the Scottish Common Sense School are those 18th century thinkers and teachers who used Common Sense philosophy to ground their work in all areas. One of the areas of the greatest success, and longevity, of Common Sense thinking was that of rhetoric.

The rhetorics of Common Sense authors, Hugh Blair (1718-1800), George Campbell (1719-1796), and Richard Whatley (1787-1863), were very much a part of the rise of the culture of belles lettres in the English-speaking world. As a part of the

${ }^{25}$ Reid, Thomas. An Inquiry into the Human Mind. p.4.

${ }^{26}$ Ibid. p. 49. 
method of belletristic reading, rhetoric became primarily a faculty of criticism, the analysis, classification, and judgement of texts, both practical and prescriptive. Belletrism and literary criticism made its way across the Atlantic by means of the Blair, Campbell, and Whately's popular rhetorical textbooks, and current-traditional rhetoric is seen as a development resulting from this process of dissemination. Since Berlin's history of current-traditional rhetoric, ${ }^{27}$ the historical argument connecting the writings of Hugh Blair and his Common Sense colleagues to its rise in the United States has been repeated too often to enable complete a listing here, but can be seen in the works of Edward P.J. Corbett, Robert J. Connors, Janice M. Lauer, Thomas M. Conley, and James Herrick. ${ }^{28}$

Of the three Common Sense rhetoricians noted above, by far the most influential in the United States was Hugh Blair, whose Rhetoric and Belles lettres alone went through over 50 re-printings, and was still being assigned as a class text as late as $1911 .^{29}$ The influence of Blair's profession of Common Sense realism is often used as an indication of his positivistic view of the rhetorical arts, and the subsequent

27 James Berlin, Rhetoric and Reality.

${ }^{28}$ Edward P. J. Corbett, Classical Rhetoric for the Modern Student (New York, 1965);

Robert J. Connors, Composition-Rhetoric: Backgrounds, Theory, and Pedagogy (Pittsburgh, Pennsylvania, 1997); Janice M. Lauer, Invention in Composition and Rhetoric (West Lafayette, Indiana, 2004), Thomas M. Conley, Rhetoric in the European Tradition (Chicago, 1990); James Herrick, The Radical Rhetoric of the English Deists: The Discourse of Skepticism, 1680-1750 (South Carolina, 1997). ${ }^{29}$ Berlin, Rhetoric and Reality, p. 2. 
development of criticism as the primary approach to both reading and rhetoric.

The Professor of Rhetoric and Belles lettres at the University of Edinburgh, Blair was an incredibly important academic and culture figure in his own lifetime in his native Scotland as part of the Scottish Enlightenment, but also through his printed works into the rest of the English speaking world. The multiple strands of politics, philosophy, economy, and culture that made up the Enlightenment converged in the Scottish universities in such as way as to form a powerful new way of teaching rhetoric and literature, arguably creating the academic field of English Literature. ${ }^{30}$ Belles lettres, the study of the writings of culture and polite society, became the focus of Scottish literature and language departments: in opposition to Oxford and Cambridge (where literary teaching continued solely to constitute Greco-Roman classical texts), the Scottish universities attempted to acculturate students by incorporating examples of genius from contemporary authors as well. Blair was a central figure in the new rhetoric of critical taste that incepted this creation, because although he and Campbell were 'deeply and honestly interested in producing ideas as sound and as current as possible, their chief desire was to produce graduates who would not be sneered at by the likes of Lord Chesterfield' ${ }^{31}$ In other words, educated Scots in the eighteenth and nineteenth centuries were keenly aware of their need to appropriate the forms and features of English high society, in order to raise their place in the burgeoning British Empire.

${ }^{30}$ Robert Crawford, 'Scottish Literature and English Studies', in The Scottish Invention of English Literature, pp. 225-246, at p. 225.

${ }^{31}$ Conley, Rhetoric in the European Tradition, p. 217. 
It is clear from Blair's publications and their reception that he did indeed popularise the belletristic study of literature, and that much of this is ascribed to his teaching on 'taste' as the cultivatable faculty of criticism. 'Taste', as it forms parts of the critical tradition, is seen as the hinge between the push for cultural conformity with discourses of power and the evolution of literary studies to literary criticism, provided by the same impulse to elitism and a positivistic epistemological framework. S. Michael Halloran tells us that 'much of great value was lost in the evolution from the neo-classical rhetoric of the late 18th century to the composition course of the late 19th...in place of the rich array of stylistic forms and techniques was the flat voice of mechanical corrections' and that this was due largely to the fact that the rhetorical virtue of eloquence shifted to a new ideal of taste, which tended 'to shift standards of judgement from a complex domain combining the moral, aesthetic, and the pragmatic to a more purely aesthetic one'. ${ }^{32}$ However, Linda Ferreira-Buckley, Winifred Horner,

${ }^{32}$ S. Michael Halloran. 'From Rhetoric to Composition: The Teaching of Writing in America to 1900 ' in James J. Murphy (ed.) A Short History of Writing Instruction from Ancient Greece to twentieth-century Century America (Davis, California, 1990), p.89. However, in his 'Introduction' to Hugh Blair's Lectures on Rhetoric and Belles lettres co-written with Linda Ferriera-Buckley, Halloran modifies this view somewhat, noting that Blair and his contemporaries 'took Quintillian as their model, and ... that their work has more in common with his program of forming citizenorators than with the narrowly circumscribed remnant to be found in the latenineteenth century textbooks of A.S. Hill and John F Genung'; Hugh Blair, Lectures on Rhetoric and Belles lettres, ed. Linda Ferreira-Buckely and S. Michael Halloran 
and Barbara Warnick ${ }^{33}$ have all offered careful readings of Blair and the Common Sense idea of 'taste' that have increasingly challenged the interpretation of the critical tradition as opposed to rhetoric. Notwithstanding these nuanced examinations, however, Blair's concern with taste is still largely historicised as an indicator of the positivistic aesthetic elitism that was the groundwork for the later tyranny of currenttraditional rhetoric.

What was Blair's own definition of taste? He argued that it should be defined as:

'The power of receiving pleasure from the beauties of nature and of art' ...hence the faculty by which we relish such beauties seems more nearly allied to the feeling of

(Carbondale, Illinois, 2005), p. xlix.

33 Winifred Bryan Horner, Nineteenth Century Scottish Rhetoric: The American

Connection (Carbondale, Illinois, 1993): Barbara Warnick, The Sixth Canon:

Belletristic Rhetoric and Its French Antecedents (Columbia,1993); Linda Ferreira-

Buckley, 'Writing instruction in Great Britain: The Eighteenth and Nineteenth

Centuries', in Murphy (ed.), A Short History of Writing Instruction (2nd edn,

Mahwah, New Jersey, 2001); Linda Ferreira-Buckley, 'Constructing Histories of

Composition Studies in America', Composition Studies, 26/2 (1998): pp. 97-112;

Linda Ferreira-Buckley, "'Scotch knowledge" and the Formation of Rhetorical Studies

in 19th-Century England', In Lynee Lewis Gaillet (ed.), Scottish Rhetoric and its

Influences (Mahwah, New Jersey, 1998); Blair, Lectures on Rhetoric, Ferreira-

Buckley and Halloran, "Introduction”. 
sense, than to a process of understanding...yet reason, as I shall show hereafter, assists taste in many of its operations, and serves to enlarge its power. ${ }^{34}$

By Blair's definition, then, the faculty of taste is an internal 'power' of response to nature and art. He carefully distinguishes it from reason: 'Reason is a very general term; but if we understand by it, that power of the mind which in speculative matters discovers truth, and in practical matters judges the fitness of means to an end...than Taste is not resolvable into any such operation of Reason. ${ }^{35}$ It is clear from Blair's work that taste itself is not a faculty of criticism; it is one of reception and mediation between the internal and external senses. Reason does, however, serve to 'assist' and 'enlarge' this faculty. This is an essential distinction to the critique of Ramism and Common Sensism's historicisation as continuous organs of the ideologies of positivism.

While the genealogical and ideological connection between what became current-traditional rhetoric and Common Sense rhetoric was increasingly named and identified, U.S. Compositionists continued to look back to even older rhetorical roots, and Petrus Ramus was grafted into this narrative. Ramus was presented, in a neat march through history, as a fitting antiquarian anti-hero for his removal of invention from rhetoric to logic, and as the link between scholastic logic and empirical reason: in sum, as the father of modern positivism. Here is how the most widely used rhetorical history textbook in U.S. graduate seminars today sums up Ramus' method:

\footnotetext{
34 Blair, Lectures on Rhetoric, Ferreira-Buckely and Halloran, p. 10

35 Ibid. p.10.
} 
By subjecting cultural studies to a supposedly universalising method, Ramus seemed to strip cultural artifacts of their culture-bound qualities. He had no use for historical knowledge. In practice, this meant that appreciation of the objects of humanist study no longer required that one be steeped in a particular historical, philosophical, or religious perspective. The method purported to give rational beings of all ages and conditions access to the great works of the human intellect-now timeless, though once originating in a particular time and place. People could gain from the humanities whatever they need for their own individual, private affairs. ${ }^{36}$

How this could be the source of what became an elitist method of criticism requires very little intuition on anyone's part. Ramus is considered the patriarch of the method of universal criticism that requires only reason as the faculty by which to see. In other words, Walter Ong's interpretation of Ramus as the proponent of a dyadic relationship between logic and truth still holds as the popular conception of Ramus' contribution to post-Renaissance rhetorical history. ${ }^{37}$

Neil Rhodes notes that because Ramus is seen as the pivotal turning point from humanism to the humanities, he is also 'responsible for the transition from rhetoric to criticism, ${ }^{38}$ and in the U.S. tradition this is taken to mean that Hugh Blair

\footnotetext{
${ }^{36}$ Patricia Bizzell and Bruce Hertzberg, 'Peter Ramus', in The Rhetorical Tradition (1990 edn), p. 560.

${ }^{37}$ Walter Ong, in Ramus, Method, and the Decay of Dialogue, p. 288.

${ }^{38}$ Neil Rhodes, 'From Rhetoric to Criticism' in Crawford (ed.) The Scottish Invention of English Literature (2008 edn), p. 26.
} 
and the influence of Common Sense rhetoric finished, or at least advanced, Ramus' rhetorical project. While this is not the place to give a historical examination of the influence of Ramism on Scottish Common Sense philosophy, there are many precursory levels at which this genealogy works. From a historical perspective, Blair and the Common-Sense realists enter onto a scene already deeply influenced by Ramist dialectic, although very little has been written about their relationship. Elizabethanne Boran tells us that at Trinity College Dudley Fenner's Ramist perspectives on dialectic and rhetoric "proved very popular with preachers who accepted logic and rhetoric as essential elements in evangelisation' ${ }^{39}$ which was also an enterprise of the Scottish Common Sense school, and reminds us that it was the Scots who brought Ramism to Dublin. As has been detailed elsewhere, the same narrative applies to the first universities in the United States, and the Scottish Common Sense rhetorics of the eighteenth century reached a new U.S. academia already deeply influenced by Puritanical Ramism. ${ }^{40}$ As the Scottish Common Sense rhetorics became widely incorporated into the curriculum of departments already indebted to Ramism, the pedagogical projects of Ramistic and belletristic reading methods - simplification of method, and the development of universal pedagogical

${ }^{39}$ Elizabethanne Boran, 'Ramism in Trinity College in the Early Seventeenth Century', in The Influence of Petrus Ramus, pp. 177-199, at p. 181. ${ }^{40}$ Perry Miller, The New England Mind: From Colony to Province (Harvard, 1954); Michael Moran, (ed.), Eighteenth Century British and American Rhetorics and Rhetoricians: Critical Studies and Sources (London, 1994). 
reading and writing methods via logical textbooks, based on a realist epistemology of language and knowledge - complimented and continued one ${ }^{41}$ another in specific ways.

In addition to a historical continuity, the cultural exigencies of the development of Ramism and the Common Sense rhetorics are comparable. S. Michael Halloran tells us that in Blair's time the shift from oratorical culture to prose composition studies was largely due to three movements: the emphasis on belletristic forms of writing; the emergence of the middle classes and professional classes in the student population; and technological developments that facilitated a heavier reliance on writing. ${ }^{42}$ I suggest that these same factors existed during Ramus' lifetime. As Erland Sellberg points out, for Ramists in Sweden supporting 'usefulness' was encouraging the training of bureaucrats and statesmen, and thus the impact of Ramism was not only theoretical, but practical for the newly-emerging political state. This, also, was the case in Blair's day, and he too wrote textbooks for a new pedagogical system that was interested in producing citizens and statesmen, in a time of a dramatic political change towards modern democracy. Of course, the newly-formed U.S. system of education and statesmanship is inexorably entwined with the same exigencies, and on the whole with the Scottish Common Sense school and Enlightenment, to such an

${ }^{41}$ S. Michael Halloran, 'From Rhetoric to Composition: The Teaching of Writing in America to 1900', in Murphy (ed.), A Short History of Writing Instruction, p. 156. 42 Erland Sellberg, 'The Usefulness of Ramism' in The Influence of Petrus Ramus, pp. 107-126, at p. 124. 
extent that more recent studies argue for a view of Enlightenment history as not a set of ideas but 'as an integral part of transatlantic networks of exchange-of ideas, people, and commodities'. ${ }^{43}$

Theoretical and philosophical similarities between Ramist rhetoric and Scottish Common-Sense rhetoric have also been suggested in light of their later pedagogical fruits. Sharon Crowley, in her paradigm-shifting examination of currenttraditional rhetoric, The Methodological Memory, tells us that the current-traditional method:

... prefers the discursive movement from generalisation to specification; it concentrates on expository discourse; it recommends that the inventional scheme devised for exposition be used in any discursive situation; and it translates invention out of the originating mind and onto the page. In other words, this rhetoric assumes that the process of invention can be graphically displayed in discourse. $^{44}$

Clearly there is a profound philosophical and logical relationship between the currenttraditional practice of teaching the arts of language and Ramus' logical method. Although Crowley tells us that 'Ramus confined...method to the presentation of

${ }^{43}$ Susan Manning and Francis D. Cogliano, 'Introduction: The Enlightenment and the Atlantic', in Susan Manning and Francis D. Cogliano (eds), The Atlantic Enlightenment (Aldershot, 2008), p. 17.

${ }^{44}$ Sharon Crowley, The Methodological Memory: Invention in Current-Traditional Rhetoric (Carbondale, Illinois, 1990), p. 13. 
knowledge rather than its generation,' she argues that it was a later development to find a method that was suited to invention. ${ }^{45}$ This later development was the work of Blair and his colleagues, whose belief in faculty psychology caused them to internalise the method in the mind of the individual. But Campbell and Blair's use of faculty psychology to cause a turn towards internalisation made 'taste', as the faculty of criticism, a faculty of internal mediation of the self towards reality at the same time as it criticises and mediates itself. In the U.S. uptake of Scottish Common Sense philosophy via Blair's work on rhetoric, this became positivistic criticism and rhetoric. But a foundational realism drawn into a movement of internal mediation and creating an individually internalised logical system did not develop into and terminate exclusively in current-traditional rhetoric. If the Scottish Common Sense school is indeed indebted to Ramism in its theoretical framework of realism and logical method for the purposes of individual mediation of the world, then it may be possible to see this debt and relationship in other branches of the outgrowth of Common Sensism. During the same period that saw the development of current-traditional rhetoric from the works of Scottish Common Sense rhetoric and logic, C.S. Peirce was reading Thomas Reid and Richard Whately for what he would later develop as his radical theories of pragmaticism and pragmatic logic. His theory of pragmatic method fits this genealogy in several striking ways.

\section{Charles Sanders Peirce and the Scottish Common-Sense School}

45 Ibid., p. 36. 
Charles Sanders Peirce, a late nineteenth-century American logician, mathematician, and scientist, developed and articulated a semiotic understanding of meaning-making that closes off neither the subjectivity of the individual mind, the relationally and communal nature of knowing, or the acceptance of the actual realness of being. He was influenced from the earliest stages of his development by the Scottish Common Sense school, as Houser points out: 'he [Pierce] claimed that from the age of twelve, after reading his brother's copy of Whately's Elements of Logic, he could no longer think of anything except as an exercise in logic. ${ }^{46}$ In later years he often acknowledged his admiration for Common Sensism, marveling at the longevity of his 'adhesion, under inevitable modification, to the opinion of the subtle but wellbalanced intellect, Thomas Reid. ${ }^{47}$ Peirce's pragmaticism has a specific debt to Scottish Common Sense philosophy, although this may seem contradictory in light of the divergent pedagogies Common Sense rhetoric and American pragmatism are customarily seen to produce. ${ }^{48}$

In his triadic theory of meaning, otherwise known as the theory of semiosis,

${ }^{46}$ Nathan Houser, 'Introduction', The Essential Peirce: Selected Philosophical Writings, ed. Nathan Houser and Christian J. W. Kloesel (2 vols, Indiana, 1992) vol.1 (1867-1893).

${ }^{47}$ Charles Sanders Peirce, 'Critical Common-Sensism', The Philosophical Writings of Peirce, ed. Justus Buchler (New York, 1955), p. 293.

${ }^{48}$ See John Boler, Charles Peirce and Scholastic Realism: A Study of Peirce's Relation to Duns Scotus (Seattle, 1963). 
Peirce describes a dynamic relationship of things as signs and the mind that perceives them. While this is not the place to fully delineate Peirce's systematic philosophy of triadic semiotic mediation, it is sufficient for our purposes to note that it is the mediation of the third, or the interpretant in the semiotic process, that allows for a position which accounts for a real world, a reasonable method, and a fully individual interpretation. All of rhetoric and logic, language, in fact our senses and reason itself, is in this Peircean world a third. This meditational process is a tool, like Blair's 'taste' for reflexivity and the creation or invention of knowledge. ${ }^{49}$

What Peirce's semiotic process indicates is the grounds for a universality of method within semiosis. Like Ramistic method, the work of semiosis is one of recognising distinctions within our logical processes of meaning; for Peirce, the method of our semiotic process is based on the habits of interpretation we develop as we distinguish things by their results. Although Peirce only ever references Ramus' work peripherally in his own writings, ${ }^{50}$ Roberta Kevelson points out that Peirce's method in its fundamental mathematical conception follows Ramus, in that it brings 'together logic and rhetoric in the domain of Method' ${ }^{51}$ Moreover, like Peirce, she

${ }^{49}$ It is essential here to note that Peirce's concept of fallibility precludes the possibility of any knowledge made being fully true in the sense that it is complete and without error.

${ }^{50}$ Charles Sanders Peirce, 'A Guess at the Riddle', The Essential Peirce, vol. 1, pp.245-280, at p. 247.

51 Roberta Kevelson, Charles S. Peirce's Method of Method (Amsterdam, 1987), p. 42. 
tells us, 'to Ramus it was not the picture in the mind that was true, but the rule of logic that "ensures that all the precepts displayed...are true," ${ }^{52}$ which is the formulation of Peircean metaphysics as well. ${ }^{53}$ Peirce declares that the method of pragmatic logic 'requires that in reasoning we should be conscious, not only of the conclusion, and of our deliberate approval of it, but also of its being the results of the premise from which it results, and furthermore that the inference is one of a possible class of inferences which conform to one guiding principle. ${ }^{54}$ Here is a flexible methodology, like Ramistic method, based on a logical system that consists of a process of seeing the effects of precepts forward and backward. Peirce's explanation of syllogistic logic thus imitates Ramus closely. ${ }^{55}$ The third, or the interpretant in

52 Ibid., p. 43.

53 Peirce has this to say: 'It is certainly very doubtful whether a conclusion - as something existing in the mind independently, like an image - suddenly displaces two premises existing in the mind in a similar way. But it is a matter of constant act from the conclusion and say that it is true. Something, therefore, takes places within the organism which is equivalent to the syllogistic process.' Charles Sanders Pierce, 'Some Consequences experience, that if a man is made to believe in the premises, in the sense that he will also be ready to of the Four Incapacities', The Essential Peirce, vol. 1, pp. 28-56, at pp. 30-31.

${ }^{54}$ Charles Sanders Peirce, 'Critical Common-Sensism', The Philosophical Writings of Peirce, ed. Buchler, pp. 290-302, at p. 293.

55 Manley Thompson, The Pragmatic Philosophy of C.S. Peirce (Chicago, Illinois, 
Peirce's triadic semiosis, is only possible by our rational process of moving from generalities to specifics. Peirce explains:

Reference to an interpretant is rendered possible and justified by that which renders possible and justifies comparison. But that is clearly the diversity of impressions. If we had but one impression, it would not require to be reduced to unity, and would therefore not need to be thought of as referred to an interpretant, and the conception of reference to an interpretant would not arise. But since there is a manifold of impressions, we have a feeling of complication or confusion, which leads us to differentiate this impression from that, and then, having been differentiated, they require to be brought to unity. Now they are not brought to unity until we conceive them together as being ours, that is, until we refer them to a conception as their interpretant. Thus, the reference to an interpretant arises upon the holding together of diverse impressions. ${ }^{56}$

Thus, while only diversity makes our distinctions possible in the first place (a crucial hinge to Dewey's later pluralistic rhetoric), the creation of the interpretant is through finding a generality. Of course, in Ramus' system, as Roland MacIlmaine tells us, 'The form and methode which is kept in this arte, comaundethe that the thing which is absolutely most clear, be first placed, and so forth with the rest. And therefore continually procedethe from the general to the special and singular. ${ }^{57}$ This

1953) p. 1-13.

${ }^{56}$ Charles Sanders Peirce, 'A New List of Categories', section 10, Proceedings of the American Academy of Arts and Sciences 7 (1868), pp. 287-98, at p. 298.

57 MacIlmaine, Logike, Dunn, p. 6. 
movement of the general to the singular is the philosophical result, or the cause (I am not certain which came first in Ramus' thinking) of his inversion of inventio and dispositio, as he considered it more natural to logic to proceed from the topics of discourse to their arrangement, which also respects the order of hierarchical necessity. Ramus says that: 'there are two universal, general gifts bestowed upon man, Reason and Speech; dialectic is the theory of the former, grammar and rhetoric of the latter. Dialectic should therefore draw on the general strengths of human reason in consideration of their subject matter... ${ }^{58}$ Because Ramus gives into dialectic the language arts of invention, arrangement, and memory, he produces in his followers (who used language for truth-telling) a method of objective-truth derivation: language can be used to represent real things, as it is distilled from our logical apprehension of real generals and real specifics. It is precisely this inversion, then, that makes the aim of Ramus' method testing the truth in language, as opposed to the aim in classical rhetoric of finding the probable.

Pragmaticism, however, does deal precisely with the probable. 'It is the reality of some possibilities,' Peirce declares, 'that pragmaticism is most concerned to insist upon. ${ }^{59}$ How can these two logical systems, based as they are on such methodological and epistemological similarity, diverge at this critical juncture? The probable, in Peircean pragmatism, is of absolute importance because the universals

\footnotetext{
58 Petrus Ramus, 'Arguments in Rhetoric Against Quintillian', in Patricia Bizzell and Bruce Herzberg (eds), The Rhetorical Tradition: Readings from Classical Times to the Present (Boston, 1990; 2nd edn 2001), pp. 563-583, at p. 566. 59 Peirce, 'Critical Common-Sensism', p. 300.
} 
are apprehended by the observation of their results in action. Pragmatic method is concerned with what is and what could be as the indicators of any universal knowledge or method - the probable is the foundation of knowledge because knowledge is necessarily created in dynamic action. This follows closely the Common Sense vision of knowledge and logic, for like pragmaticism, Common Sense universals are observed according to their results (for instance, on our faculties of apprehension). However, it may be that from an epistemological standpoint the probable is not such a divergence between Ramus' and Peirce's logical method. For Peirce, we move from the general to the specific because everything that is is already in motion, and the phenomena we observe in specifics are already mediations. For Ramus, 'the cause is that by whose force the thing is: and therefore this first place of invention is the fountain of all sciences: for that matter is known perfectly, whose cause is understood.' The cause, therefore, is what pushes a thing to be manifested as it is in the real world, and like Peirce and the Scottish Common Sense philosophers, Ramus argues that language is instantiation of a cause becoming itself as it instantiates its mediation. To all three there are profound moral dimensions to the use of logic and language. Even though dialectic (as it pertains to reason) and speech (as it pertains to rhetoric) are separated in Ramus' logical system, nevertheless even he declares 'in use these should be united, so that the same oration can expound purely, speak ornately, and express thought wisely'. ${ }^{60}$ They must be separate, therefore, because to distinguish and make visible is how we learn, not how dialectic and

${ }^{60}$ Ramus, 'Arguments in Rhetoric Against Quintillian', p. 566. 
rhetoric manifest in the world, nor how we actually use them.

The significance of the methodological overlap between Peirce and Ramus should not be underestimated, especially in relation to the pedagogical projects that have been produced by Pragmatic rhetoric, which are to a great extent the epistemological and methodological opposites of current-traditional rhetoric. While current-traditional rhetoric, as an offshoot of Ramist influences, created a pedagogy rooted in criticism and 'concerned about the quality of authorial minds' ${ }^{\text {'61 }}$ with all of its overtones of elitism and positivism, Pragmatic rhetoric became the bedrock of socially-epistemic rhetorical practice which maintains individuals while accounting for a practice of pluralism.

\section{Ramus, Current-Traditional Rhetoric, and Peircean Pragmaticism: Similarities and Differences}

Finally, there are three important areas of interrelationship connecting Peirce to the nexus of Ramus and the Scottish Rhetorics. First, all three, as forms of specifically Christian realism, point to the fact that everything that is, is of a representative nature. Peter Sharrat tells us that Ramus 'adopts the Christian synthesis of neo-Platonism and the gospel...he manages to combine that idea that reality, as we think we know it, is once removed from true reality, and art is twice removed, with the idea that art and philosophy somehow bring out the universals in nature'. ${ }^{62}$ Peirce

61 Crowley, Methodological Memory, p. 13.

62 Peter Sharratt, "Peter Ramus and Imitation, Sign and Sacrament" in Yale French Studies, 47 (1972): pp. 19-32, at p. 27. 
tells us that everything that is capable of being represented is itself representative and that we represent through semiotic mediation. Second, all three transpose this notion into a universal method for seeing distinctions, differences, and organising our response to them. Ramus purports his method of logical deduction; Common Sensism gives us the development of taste and sensibility as a mediated method of knowing and responding; and Peirce delivers what would become in the hands of James and Dewey the 'experimental method' of allowing what something does to define what it is, in which contextual knowledge brings us directly back to the open hand of rhetoric. And the third similarity is that they all make the specific human faculty of reason, in its capacity to distinguish, the means of logical mediation between nature, self, and society.

An important difference to bear in mind is that Blair's project was in specific response to Empiricism, and is thus distinct from Ramus in its emphasis on emotion and experience in conjunction with the real and the social. Brian Short tells us that Scottish Common Sense rhetoric's 'genius is...for psychologising traditional tropes and giving them a force which transcends not only the canon of style, their classical locus, but the boundary which separates rhetoric from epistemology and moral philosophy'. ${ }^{63}$ It is this movement, which privileges a single mind and thus sees texts as the reflection of the working of an authorial mind, that Sharon Crowley argues is the foundation for rhetoric based. However, this which is also expressed in Peirce's

${ }^{63}$ Brian Short, 'Figurative Language and the Scottish New Rhetoric', in Language Sciences, 22/3 (2000): pp. 251-264, at p. 256. 
triadic dynamism, also accounts for an epistemology and moral philosophy that moves inwards and outwards, incorporating as it judges and mediates - a practice that is at once socially-epistemic and methodologically logical. Realistic method does not, in the end, lead exclusively to scientific positivism with all of the concurrent pitfalls of criticism. If, as Catherine Dunn suggests, Ramus' method were seen as a 'useful tool for demonstration, rather than a science of human reason', then the ideological, philosophic, and historical continuities between Ramus, Scottish Common Sense rhetoric, and Peircean pragmatic method would be united, by virtue of the fact that they all methodise to find truth in a way that assumes a universal method based on a realistic view that is not itself dyadic or positivistic.

\section{Conclusion}

What this chapter has shown is that the ideological trajectory from Ramistic method to current traditional rhetoric, via the Scottish Common Sense school, is significantly complicated by the debt that Peircean pragmatic method (and by extension, American pragmatism) owes to Common Sense rhetorical and logical epistemology of language; and the readily visible methodological overlaps in turn between Ramistic and Pragmatic method. All three schools of method share a philosophically realist premise in which logic is specifically oriented to action- in Ramus, to the action of making visible the logical system of invention within language, in Peirce and the Scottish Common Sense thinkers to a final concern for civic and social interaction through one's reflexive mediation of reality through language. The broader philosophical implications of this argument is the re-evaluation 
of the current assumption that logic, if it is based on a realist premise, necessarily removes rhetoric from any function other than the managerial and perfunctory. As a final thought, at this juncture in the study of rhetorical theory and history, we might see this observation as a move to the post-critical; and one in which all methods of knowledge-making can be viewed, not as controversial or condemnable lapses into antiquated systems of philosophy, but as useful and inclusive tools to mediated knowing in a mediated world. 


\section{Bibliography}

Berlin, James A. Rhetoric and Reality (Carbondale: Southern Illinois University Press, 1987).

Bizzell, Patricia and Bruce Herzberg. "Peter Ramus, 1515-1572" in Patrica Bizzell and Bruce Herzberg (eds.) The Rhetorical Tradition: Readings from Classical Times to the Present (Boston: Bedford of St. Martin, 1990) 557-562.

Boler, John. Charles Peirce and Scholastic Realism: A Study of Peirce's Relationship to John Duns Scotus. (Seattle: University of Washington Press, 1963).

Boran, Elizabethann. "Ramism in Trinity College in the Early Seventeenth Century" in Mordechai Feingold, Joseph S. Freedman, and Wolfgang Rother (eds.) The Influence of Petrus Ramus (Basel, 2001) 177-99.

Conley, Thomas. Rhetoric in the European Tradition (Chicago: Chicago University Press, 1990).

Connors, Robert J. Backgrounds Theory, and Pedagogy (Pittsburgh Series in Composition, Literature, and Culture) (Pittsburgh: University of Pittsburgh Press, 1997).

Corbett, Edward P.J. Classical Rhetoric for the Modern Student (New York: Oxford, 1965).

Crowley, Sharon. The Methodical Memory (Carbondale: Southern Illinois University Press, 1990).

Fogarty, Daniel. Roots for a New Rhetoric (New York: Russell and Russell, 1959).

Halloran, S. Michael. "From Rhetoric to Composition: The teaching of Writing in America to 1900" in James Murphy (ed) A Short History of Writing Instruction from Ancient Greece to $20^{\text {th }}$ Century America. (Davis, CA: Hermagoras Press, 1990).

Herrick, James A. The History and Theory of Rhetoric: An Introduction (Boston: Allyn and Bacon, 2001)

Horner, Winifred Bryan. $19^{\text {th }}$ Century Scottish Rhetoric: The American Connection (Carbondale: Southern Illinois University Press, 1993)

Kevelson, Roberta. Peirce's Method of Method (Philadelphia: Johns Benjamin Publishers, 1987).

Lauer, Janice. Invention in Rhetoric and Composition (West Lafayette, IN: Parlor 
Press, 2004).

Manning, Susan and Francis D. Cogliano . "Introduction: The Enlightenment and the Atlantic" in Susan Manning and Francis D. Cogliano (eds.) The Atlantic Enlightenment (Aldershot: Ashgate, 2008)1-18.

MacIlmaine, Roland. "Introduction to Ramus' Logike". The Logike of Peter Ramus, tran. Roland Mac Ilmaine, ed. Catherine Dunn (Northridge, CA: San Fernando Valley State College, 1969).

Meerhoff, Kees. "Melanchthon, Latomus, Ramus: Teachers of Careful Reading" in Ton Hoenselaars and Arthur F Kinney (eds.) Challenging Humanism: Essays in Honor of Dominic Baker Smith (Newark: University of Delaware Press, 2005) 90-107.

Miller, Perry. The New England Mind: The Seventeenth Century (Cambridge, MA: Harvard University Press, 1963).

Peirce, Charles Sanders. "A New List of Categories" in Proceedings of the American Academy of Arts and Sciences, Volume 7 (Proceedings of the American Academy of Arts and Sciences: Boston, 1868).

Sellberg, Erland. "The Usefulness of Ramism" in The Influence of Petrus Ramus ed. by Mordechai Feingold, Joseph S. Freedman, and Wolfgang Rother (Basel: Schwabe \& Co., 2001)107-126.

Short, Brian. "Figurative Language and the Scottish New Rhetoric." Language Sciences. 22/3, (2000): 251-264.

Thompson, Manley. The Pragmatic Phiolsophy of C.S. Peirce (Chicago: University of Chicago Press, 1963).

Warnick, Barbara. The Sixth Canon: Belletristic Rhetoric and Its French Antecedents (Columbia: University of South Carolina Press, 1993). 


\section{MANUCRIPT THREE}

Keefe, Rosaleen. “Common Sense Rhetorical Theory, Pluralism, and Protestant

Natural Law." The Journal of Scottish Philosophy 11.2 (2013): 213-228 DOI:

$10.3366 /$ jsp. 2013.0057

(C) Edinburgh University Press www.euppublishing.com/jsp

Copyright of Journal of Scottish Philosophy is the property of Edinburgh University

Press and its content may not be copied or emailed to multiple sites or posted to a

listserv without the copyright holder's express written permission. However, users may

print, download, or email articles for individual use. 


\begin{abstract}
This paper offers re-assessment of Scottish Common Sense rhetoric and its relationship to pluralist practice and philosophical method. It argues that the rhetorical texts of George Campbell, Hugh Blair, and Alexander Bain can be read as a practical application of Scottish Common Sense philosophy. This offers a novel means of examining the relationship that Scottish rhetoric has to the philosophy of David Hume and also its own innovative philosophy of language. Finally, I argue that Scottish rhetoric makes a unique contribution to rhetorical methodology's key place in the creation of social and moral consensus.
\end{abstract}

Key Terms: rhetoric, George Campbell, philosophy of language, philosophical method, pluralist rhetoric, natural law 


\section{Preface}

This journal article was expanded from a paper delivered at the Center for the Study of Scottish Philosophy at Princeton Theological Seminary, in response to a call for papers examining the "Scottish Common Sense Philosophy and the Natural Law Tradition in America." The conference was a part of the celebration for the bicentennial of the PTS, and my paper won the "George Elder Davies Prize for Best Graduate Paper." I was informed by the conference organizer that my paper won because the peer-reviewers agreed that among the submissions it best pointed out genuinely new directions for philosophical inquiry within the field. Rhetorical theory and its relationship to the philosophical tradition is a lesser-studied branch of Scottish philosophy, and this paper approaches the "natural law" tradition from the rhetorical standpoint. Perhaps more than the other two manuscripts included in this dissertation, this manuscript represents more the promise of new angles of inquiry than a fully elaborated argument. Its close reading of the rhetorical texts for the re-interpretation of their epistemological foundations is certainly unusual in traditional criticism of Scottish Enlightenment philosophy, and demonstrates the advantages of interdisciplinary study and methodological background in English literature and Rhetoric and Composition. 


\section{TEXT}

The philosophical heritage of Scottish rhetoric has been in a contested state for some time. Some, such as Janice Lauer, claim that 'its purpose was not to investigate or create, but rather to organize and present arguments through moral reasoning and empirical evidence.' ${ }^{1}$ Others, such as Thomas Conley, interpret it more for its role in the eighteenth-century project of social mobility:

Both Campbell and Blair...stood stolidly in the tradition of rhetorics designed to transform students into gentlemen ... If both were intent on incorporating recent advances in philosophy into their conceptions of what rhetoric was and how rhetorics ought to be composed, both were nevertheless mainly concerned with initiating youth into the beau mode of belles lettres, as it were. ${ }^{2}$

Most rhetorical criticism interprets Campbell's and Blair's rhetorical work as a largely derivative synthesis of new Enlightenment philosophical methods and the classical Latin rhetorical works of Cicero and Quintillian, with enough Common Sense realism and French belles lettres to make them broadly applicable as prescriptive classroom texts, dictating style and taste for many decades. These interpretations all have their

grounding. However, I argue that if Scottish rhetoric is read as a theorized practice of Scottish Common Sense philosophy, it can be interpreted as far more rhetorically innovative and morally farsighted than these contemporary interpretations allow. Far from following basic Enlightenment philosophy of mind but inserting a Common 
Sense epistemology to the detriment of any substantial rhetorical renovation, I put forward that Campbell and Blair, and the Common Sense school of which they are a part, create an insightfully inventive theory of language and its use. This new Common Sense philosophy of language reunites Logic and Rhetoric, which had been separated in Protestant teaching since the work of Petrus Ramus. They do this via a rhetorical theorization of Common Sense philosophy's realism in conjunction with Hume's philosophy of mind. The realist vision of language that emerges from the rhetorics of George Campbell, Hugh Blair, and, later, Alexander Bain, presents an understanding of language in which verbal communication - by virtue of its unique place in human reasoning - is recursive, and therefore progressive; relational, therefore social in its inception and product; natural, thus subject to universal laws; and finally, perhaps most importantly of all, is inherently a method, or praxis of inquiry and knowing. I suggest broadly that their rhetorical method, far from being a historical phenomenon limited to its historical contexts, may be more useful if seen as philosophical praxis that can be examined by its philosophical, pedagogical, and conceptual productions. These productions are multiple, often contradictory to one another, and continue to the present day. Further, the rhetorical theory presented in this reading of Hume, Campbell, Blair, and Bain clearly articulates the juncture between moral education, civil and civic conversation, personal and public virtue, and the means of creating the kinds of moral consensus necessary to religiously plural societies.

First it must be noted that the outcomes or possibilities of Scottish rhetoric's facilitative roles in moral consensus are historically seen far later than the Enlightenment and Victorian time periods that produced them. It is beyond the scope 
of this paper to do more than point to the conceptual frames at work in the rhetorical theories; further work would be needed to outline their linkages to latter inceptions of religious and moral pluralities. ${ }^{3}$ The arguable claim here is that Scottish rhetoric conceptually anticipated the need to address a secular or religiously plural state. Stated conversely, in Scottish rhetoric was found a serviceable way to address this need as it did arise. ${ }^{4}$

The Scottish Common Sense rhetorical project offers a keen reinterpretation of Hume's philosophy of mind by articulating a more exact role of sentiment, sympathy, and feeling in the social processes of belief and judgment. Campbell's Philosophy of Rhetoric (1776) especially performs this work, although it is widely interpreted as so derivative of Hume's and Reid's ideas that its original contributions to rhetorical theory are often overlooked. Lloyd Bitzer tells us that 'In Hume's Treatise, and in the later works which dressed up the doctrines of that work, are to be found the principal theories found in Campbell, the major exception being the view of common sense truths, surely developed in Campbell's discussions with Thomas Reid.'5 Indeed, Campbell's reputation for contributing to the Common Sense philosophical project rests more on the influence of the Rhetoric as a widely-used textbook in the eighteenth- and nineteenth-century classroom than on his original philosophical thinking. Marc Hanvelt, in The Politics of Eloquence (2012), follows Arthur Waltzer's and Lloyd Bitzer's evaluation that, appropriating Hume, George Campbell's art of rhetoric is making language use best resemble sense impression. ${ }^{6}$ Hume's own theories of rhetoric are grounded in his philosophy of the mind, as he wrote surprisingly very little explicitly on a co-extensive philosophy of language or 
rhetorical theory. ${ }^{7}$ It has been argued that George Campbell's work is as close as one may come to extrapolating Hume's philosophy of mind into a coherent rhetorical theory. ${ }^{8}$ Hume, of course, placed judgment and persuasion in the arena of the understanding: the faculty of probable, or inductive, reasoning. Reason, on the contrary, is the realm of the direct, intuitive, and demonstrable. In a Humean system, therefore, rhetoric is not needed in the deductive reasoning processes, or any area of knowledge that is strictly logical (such as mathematics). This is in direct opposition to the Ramistic rhetorical systems, in which rhetoric is seen as precisely the tool for communicating, in the most logical manner, that what is logical. For Hume, Smith, Campbell, and Blair, rhetoric is returned to the art of the probable. ${ }^{9}$ The probable is also a central concept in Hume's epistemology, and more importantly, in his idea of the social and moral. After all, dictated by the probable, custom is the 'great guide of human life' and 'all inferences from experience, therefore, are the effects of custom, not of reasoning. ${ }^{10}$ In the mental process, the ability to create the conditions of connection (resemblance, contiguity, and causation) are passionate (and sympathetic, in instances of communication) processes first and foremost. These alone inspire belief and motivate action. For Hume, judgment and belief arise from customary associations of lively impressions that produce a strong feeling in the mind - as opposed to perceptions of actual causality, faculties of sentiment are the motor of understanding. Hanvelt points out that for Hume rhetoric is therefore the art of making lively and vivid resemblances in order to induce belief, for 'ratiocination' and impression, or imagery, are basically one in the same. ${ }^{11}$ Rhetoric for Hume is thus a moral art for the discovery of belief and motivation based upon the probable, not a logical art for the 
discovery of truth or falsehood based upon the reasonable.

George Campbell is happy to employ many, if not most, of these ideas in his philosophy of rhetoric. ${ }^{12}$ As Bitzer points out, in the Rhetoric Campbell cites Hume 'four times more often than Thomas Reid, five times more than Locke, and nearly three times more often than Bacon.' ${ }^{13}$ If, however, Campbell almost entirely and unquestioningly assimilates Hume's epistemology in the Rhetoric, it would indicate either 1) a rather puzzling inconsistency in his own personal philosophical and religious belief (as he certainly did not accept Hume's skeptical conclusions), or 2) a more innovative view of rhetoric than has previously been ascribed to him: one that explains and synthesizes Hume's philosophy as proper to a philosophy of language and theory of rhetoric. This latter interpretation explains the discrepancy, as it confines Hume's skeptical conclusions to the area of human capacity to which they are undeniably fitted. ${ }^{14}$

Campbell declares that while 'belief commonly enlivens our ideas . . . vivacity of ideas is not always accompanied by faith, nor is faith always able to produce vivacity. ${ }^{15}$ But, if indeed Hume and Campbell agree that rhetoric is making language use resemble sense impression, then Hume's use of rhetoric to affect reason is ultimately more coherent than Campbell's, and Campbell, as Hanvelt and Walzer point out, simply recreates the old idea that the art of rhetoric is one of the managerial purpose of making language more persuasive. A close reading of Campbell would indicate that his intentions are otherwise.

In his 'Introduction' to the Philosophy of Rhetoric, Campbell outlines his epistemic project for language: 
'Logic, whose end is the discovery of truth, is founded in the doctrine of the understanding: and ethics, (under which may be comprehended economics, politics, and jurisprudence) are founded in that of the will ... but these are not the only arts which have their foundation in the science of human nature ... there is no art whatever that has so close a connexion with all the faculties and powers of the mind, as eloquence, or the art of speaking, in the extensive sense in which I employ the term $\ldots, 16$

He continues to elaborate the relationship between language and the human faculties: 'this study, properly conducted, leads directly to an acquaintance with ourselves: it not only traces the operations of the intellect and imagination, but discloses the lurking springs of action in the heart. ${ }^{17}$

The science of language, therefore, is the science of the mind; deeper yet than the mind, it is the science of volition. Further, its method of knowing the mind is one of deduction from the close observance of language already in use. Campbell breaks this down into four steps, clearly announcing the fourth step as the place where his philosophy of rhetoric breaks with the old rhetorical traditions and offers something new. The first step in the 'attainment of this art' is to observe the 'practical experience of mankind, which individuals, even in their rudest state, are capable of acquiring' (that is, there is no human society or individual in which language is not operating at some level). The second is the beginning of the 'critical science' of observing which modes of speech and argument are employed for the 'purposes of explaining, convincing, pleasing, moving, and persuading'; the third is to compare the effects, taking in circumstantial evidences. The fourth is to "canvass those principals in our 
nature to which the various attempts are adapted, and by which, in any instance, their success or want of success may be accounted for'. This fourth and last step, he tells us, 'may be said to bring us into a new country, of which, though there have been some successful incursions occasionally made upon its frontiers, we are not yet in full possession. ${ }^{, 18}$ While it may seem that the entire art of rhetoric is contained within steps one through three, the intervention of step four is to define the art of rhetoric as epistemic. In order to understand how to effectively use language, Campbell contends that one must understand how language use operates upon those "principals in our nature' by which we understand, are pleased, are moved, are persuaded, and act. Alternatively, it could be said that in order to understand the principals of our nature, we may look to acquiring the arts of rhetoric. Language use, in Campbell's estimation, does not serve to find the best ways to resemble sense impressions, as Hume indicates, nor does it offer tools to manipulate other minds through impressions, as sophistic rhetoric uses knowledge of the audience. Rather, it is both the form and the method of inquiring how the mind operates, as the means to directing operations of the mind. This is consonant with Reid's contention that knowledge is not certain because it is infinite and our faculties finite: in Campbell's scheme, rhetoric is safeguarded from the charge of sophism by the education of both the rhetor and the audience. All of the participants within a civil discourse should, to varying degrees, have the opportunity to learn the rhetorical arts, which coincides also with the formation of taste. And, of course, these means must be properly guarded by Christian virtues. Therefore, using and knowing human circumstances in conjunction with a 'science of the mind' is not a stable and permanent body of knowledge; rather it is a finite and fallible practice in 
which the listener and speaker have equal roles.

Campbell makes his reunion of logic and eloquence plain in Chapter IV: 'eloquence,' he states, considers 'not only the subject, but also the speaker and the hearers, and both the subject and the speaker for the sake of the hearers, or rather for the sake of the effect intended to be produced in them.' Because of this, it unites an equal concern for truth and its effects. Logic is to rhetoric what the soul is to the body, what sense is to expression, that is, the animating principal. ${ }^{19}$

Grammar is the purely contextual managerial art; eloquence, in its fullest capacity, is the dynamic, flexible method of uniting sense to expression: via a science of the mind and a science of analyzing and using context. 'Now', Campbell explains,

if it be by the sense or soul of the discourse that rhetoric holds of logic, or the art of thinking and reasoning, it by the expression or body of the discourse that she holds of grammar, or the art of conveying our thoughts in words of a particular language . . The art of the logician is accordingly, in some sense, universal; the art of the grammarian is always particular and local..$^{20}$

But he has already established that this art of the logician is the art of thinking and reasoning and that this is not through inductive operations of the mind apart from sense but rather through the inductive process of seeing how the mind is already working by observing its uses (in language). The realist concept of rhetoric which emerges sees a universal, natural, common sense understanding of language use as refracting the use of language in the mind's coming to know. It is a circular but not a 
closed process, ${ }^{21}$ as the application (and similarly the inquiry, as it also is in language) is always through the infinite variety of the particular, local and contingent.

The purpose of the language faculty in the Common Sense rhetorical vision is moral and social:

Reality or fact comprehends the laws and the works of nature, as well as the arts and institutions of men ... by the first, we must acknowledge, when applied to things, and combined with the second, our researches into nature in a certain line are facilitated, the understanding is enlightened, and many of the arts, both elegant and useful, are improved and perfected. Without the aid of the second, society must not only suffer but also perish. Human nature itself could not subsist. ${ }^{22}$

This practice of inquiry is also recursive: that is, it informs, perfects, and corrects both the faculties and their result as it operates for the purpose of both knowing in the first place and in the second using knowledge for the creation and betterment of the social and inter-relational realm. Hugh Blair develops and explains this as the rhetorical cultivation of taste.

Blair is most interested in how one uses rhetorical arts for the cultivation of taste as through this cultivation society can achieve moral understanding. He outlines his philosophy of language in the introduction to Lectures on Rhetoric and Belles lettres thus:

Speech is the great instrument by which man becomes beneficial to man: and it 
is to the intercourse and transmission of thought, by means of speech, that we are chiefly indebted for the improvement of thought itself. Small are the advances which a single unassisted individual can make towards perfecting any of his powers. What we call human reason, is not the effort or ability of one, so much as it is the result of the reason of many, arising from lights mutually communicated, in consequence of discourse and writing. ${ }^{23}$

In Blair's particular and poetic explanation, taste and language are transactional, as by their practice they move between the individual's innate faculties and capacities and the discourse, and therefore taste, of others. Blair makes very clear that like Campbell he places experience as the basis of this dynamic, and rules out a priori principles or deduction - 'The rules of criticism are not formed by any induction a priori, they are not formed by a train of abstract reasoning, independent of facts and observations. ${ }^{24}$ But he also believed that the social episteme of taste was indeed from the given and universally shared foundation of human nature as created by God. Eloquence and taste are the reflexive tools that we use to access our universal love of the good and beautiful: 'In every composition, what interests the imagination and touches the heart pleases all ages and nations. There is a certain string, to which, when struck, the human heart is so made as to answer. ${ }^{25}$ Thus the problem, and possibility, of rhetoric increases its power as an ethical project in that it moves from the being only the vehicle of social and personal improvement to being the very context through which we create knowledge and experience truth.

When Blair declares that reason itself is the consequence of discourse and 
writing, he gives a profound grounding to the necessity of educating the faculties of taste, that is, the capacity to be moved. Reason, while socially epistemic in Blair's conceptualization, is not therefore dependent entirely on the whim and winds of social convention as it is made to respond to what is universally true. However, the filterthe transactional, relational parts in the mind and heart that mediate between the universal and the individual - is the faculty of taste, which is developed and cultivated through language use, and therefore is subject to social convention. The creation of social conventions through shared taste and language practice is an essential element of moral life.

From Campbell we get a clear picture of how the Common Sense Philosophy of Rhetoric diverges from previous theories of language, in its realist and methodological orientation; from Blair we see even more acutely how recursively social its foundation and its uses are. From Alexander Bain, ${ }^{26}$ we get a decisive philosophical articulation of the limitations of language, relative to its function in rationality. Bain's underlying philosophy of language is very pragmatic, or, more fittingly, pragmaticist: he states that language is fundamentally limited by that fact that a word and a concept exist only in relationships that language has to allude to or assume. He calls this the "essential doubleness of knowledge, disguised by the forms of language. ${ }^{27}$ By doubleness he is referring to 'the fact that our mind works by contrast ${ }^{28}{ }^{28}$ so Bain specifically refers to the rhetorical tool of antithesis - but doubleness just as well refers to the plurality of knowledge, to which he also refers. Bain, like Campbell and Blair, considers that rhetoric, as 'knowledge of the persons addressed' ${ }^{29}$ requires a complete 'systematic scheme of man's nature. ${ }^{30} \mathrm{He}$ is also 
very lucid in elaborating the social-episteme of this knowledge. He delineates the tools of the rhetor as 'the practical maxims acquired by men in the course of their education and experience, their principles of action, or rules of procedure trusted for gaining their ends, individual or social; these are the data of the orator, his medium of persuasion, the major premises of his reasonings. ${ }^{31}$ This theory of rhetoric is deeply embedded in the contextual nature of human relations, and, more than an art applying itself to man, it is to a real degree the art of man, combining as it does 'all the arts of strengthening or of loosening the bonds that cement ideas in the mind. ${ }^{32}$ For Bain, the 'essential plurality of knowledge ${ }^{33}$ that he describes as the multiple and possibility infinite connections each person makes in their processes of knowing - occurring through distinction and contrast—cannot be represented in language. It is the essence of the art of rhetoric to find ways of creating in hearers the processes of knowing.

For the Scottish Common Sense rhetors, the project of understanding, applying, and teaching rhetoric was one and the same as the project of common sense: more than an extension of common sense philosophical principals, it is the practice of these principles. And it is moral practice, as it is directed at every stage toward creating our capacity as we understand and use that capacity. Its uniquely empirical realism accounts for a universal in the nature of humanity: we are universal language users, we deduce from our language use the way the mind operates. Further, we can deduce the ways we operate socially from the ways we can act upon one another through language. The mere fact of these natural functions is not enough to direct their usage in natural ways: because they only operate contextually (there is no language without a grammar, for instance), we must be educated to analyze and understand the 
contexts in order to use the function, as we ourselves are within those contexts. There is no removal or abstraction from the fundamental reality of relationships, of contexts, of being within a dynamic. This human science of rhetoric is a unique marriage of the changeable and the same, and of the inductive and the deductive. Of course, for Campbell and Blair (less so for Bain and Hume) there is a final grounding in the ontology of being as Creation. However, its method requires no revelation to be either known or used. Its science is operationally secular, in the sense that, other than a warrant in the Creator, it refers to nothing outside of the nature of man as observed in and through his natural contexts.

Thomas Reid taught a special '12 o'clock class' at Glasgow University, a class, Peter Diamond tells us, which was 'devoted to the practical application of philosophy. ${ }^{34}$ It is not a quaint eighteenth-century archaism that this instruction often turned to 'eloquence'. ${ }^{35}$ I argue that rhetorical practice, in fact, is precisely the practical application of Reid's philosophy, which is one reason the Common Sense school produced the multiple rhetorical textbooks successfully and extensively used throughout the English-speaking world for the next two hundred years.

Campbell tells us that, 'On the most sublime of all sciences, theology and ethics, is built the most important of all arts, the art of living' (Campbell 1776: lix). Reid's idea of common sense, by his own admission, must be come to by the practice of virtue, as the 'power of reflection', while a natural power, only comes through development into maturity, and 'to acquire this habit, is a work of time and labour' ${ }^{36}$ He appeals to ordinary language and to attention to language altogether as the proper first subject of deductive observation. Campbell's correlation of language and the 
workings of the mind directly follow Reid's analysis in Essays on the Intellectual Powers of Man. ${ }^{37}$ Thus, of the first objects upon which to exercise the powers of reflection, language, like man's other faculties, is found in an already working and dynamic state. Therefore, the study of language exercises both the habits of reflection and the practice of the art of living, once again, in a dynamic recursive relationship they perfect as they inform one another. Virtue, in this knowledge economy, is also a recursive function that acts as both the beginning and end of the process, but it must be cultivated, practiced, reflected upon, learned. Like language, virtue is an action (even of attitude), oriented equally towards using and perfecting inner faculties and towards the social and outward effects.

The epistemic nature of language to reason in the Scottish Common Sense philosophy of language rests on the belief that they share with Hume in the centrality of emotion, feeling and sentiment in the processes of judgment. The strong emphasis on Eloquence, in both the philosophical systems and in the public teaching practices of Francis Hutcheson, Smith, Reid, and Blair, indicates clearly the essential importance of the language arts in the training of sentiment and sympathy and all that those terms invoke within their philosophical systems. Unlike Hume, however, the Common Sense thinkers distinguish between the means of knowing and what can be known - the rhetorical means to socially constructed knowledge: the creation of belief, and the structures of civil and personal customs of association, does not obviate the fact that truths do exist, even if we only know them through probable, finite, and imperfect means. ${ }^{38}$ There is no final skeptical conclusion in the Common Sense rhetorical vision, only an explanation of how, and why, our conclusions are always conditional and 
fallible (and therefore, like in the Humean system, open to revision and expansion).

The history of the impact of the Common Sense rhetoric is perhaps inestimable. Whether or not citizens of English speaking countries went on to pursue higher educations and philosophical speculations, the rhetorical textbooks were used widely enough to have reached almost every educated person of several generations, informing and codifying language practices. But this had its drawbacks. As the century passed the dynamic rhetorical theory and language philosophy that informed these texts was lost in what became the prescriptive nature of rhetorical studies: the five paragraph essay, the positivist critical practices, the overwhelming attention to stylistic markers of taste and class. Scottish Common Sense Rhetoric, because of its realist orientation to universal truths, became the source of what is now called 'currenttraditional rhetoric, ${ }^{39}$ the teaching of language as an objective sign system. This, considered alongside Blair's later reputation for crafting a project of 'taste' that resulted in an oligarchy of taste-makers, and the reputation of Scottish rhetoric, by the late twentieth century, was dismal and canonical.

There is another trajectory of Common Sense language theory, however, founded in the work of C.S. Peirce. I would argue that these two conceptual trajectories could not be farther apart, although they share a foundation. Peirce, who credits his childhood turn to philosophy to reading Richard Whately, and late in life admits that he never shook his love for the 'old Scots' ${ }^{40}$ created the method of 'realist pragmatism' via his concept of a triadic semiotic, which is nothing if not a recasting of rhetorical theory. His methods of abduction and semiotisis share Scottish rhetorics' concern for both inner virtue and social morals; his 'speculative rhetoric' shares its 
epistemological project. James Jacob Lizka reminds us that Peirce joins truth and inquiry: 'by true is meant at that which inquiry aims', and that 'taken in these terms, formal rhetoric becomes the study of how to best adapt inquiry to achieve truth. ${ }^{41}$ Much could be said regarding Peirce's 'speculative rhetoric' of 'pragmaticism', and how in the hands of his students and contemporaries, it became the American pragmatic school best known for its Progressive education (via Dewey) and its theory of pragmatic liberalism in politics. Suffice to comment that the legacies of Dewey's progressivism couldn't be further from the positivist language teaching credited to Common Sense rhetoric by Rhetoric and Composition studies today. ${ }^{42}$

Thus in America, on the one hand Scottish rhetoric produced a body of language use and teaching that was almost purely positivist in its outlook and methods; on the other hand it produced a body of language use and praxis that was purely pluralist and social-constructivist. This, I believe, speaks to its complicated realism, and use of what might very tentatively be called a 'Protestant natural law' philosophy of language.

While hardly a novel claim, the hinge for interpreting Scottish rhetoric has its focus on the project of virtue, or moral betterment of civil society. In the work of Campbell, Blair, and Bain, the reinstatement of 'inventio' through the union of logic and eloquence in the Common Sense epistemology results in a coherent theory of how our language use refracts our faculties and capacities.

It is profoundly relational, from its internal relation of faculties to one another and the outside world, to the outside world's infinitude of relationships. By Scottish rhetoric's recursive art of knowing ourselves through knowing our audience, it 
premises not unfaltering principals of rhetorical knowing, but a method of praxis/a practice of inquiry.

As a method, the Scottish rhetoric utilizes two conceptual frameworks, which each inform knowledge of the other: 1) the historical, cultural, and local nexus of practices and ideas in language, and 2) a concept of a natural and universal law.

This practice, from Reid onward, converges on the teaching of eloquence, for the first inherent reason that our faculties of knowing must be facilitated through this practice, and for the second that our faculties of knowing effect and affect the premises for discourse, and thus, the substance and context of civil life. Scottish philosophy saw, as did the classical writers they admired, that the rhetorical arts create the social order. But unlike other moments of civil society, the Scots had to address the new order of a religiously fractured state. While Scottish society was profoundly Christian, the doctrinal, ecclesiastical, and theological practices of the Scottish Protestant traditions of Christianity were contested (although not with as much genuine difference as in America, England, or Continental Europe). The Scottish rhetors were champions of religious tolerance in their own society, and they developed a system that, because of its realist orientation, could sustain and work in a reasonably uncommitted external way. The entire project of the art of rhetoric is to find and form a basis of moral consensus using a flexible method of inquiry.

Pluralistic societies require just such a tool, which the Scottish Enlightenment assessed. The challenge, says Donald J. Wolf, S.J., (writing in the 1960s), is to 'form a moral consensus in a society which is, and will remain, pluralist. ${ }^{43}$ Current theories of pluralism confront questions posed by societies in which moral differences run so 
counter that it is difficult, if not impossible, to find genuine consensus, and the resulting rhetoric and discourse is failed and hollow. We very often see politics as sophism at its worst, and yet, 'democratic societies that are fully committed to freedom of religion have decided there are certain norms and values so fundamental to human existence and so deeply held that religion cannot be used as a basis for their violation. ${ }^{44}$ There must be moral consensus on recurring levels, and this must happen through citizens who exercise internalized habits of mind through and within civil discourse. This is what Wolf calls 'an attitude about the conditions of cooperation', ${ }^{45}$ and what Alistair MacIntyre terms 'tradition-transcendent rationality. ${ }^{46}$ What I suggest here is that the Scottish Common Sense school offered a deeply theorized method of inquiry in the form of their Common Sense realist rhetorics in answer to this need in their modern pluralist democracy. This method, I further hypothesize, is a crucial moment in the history of Protestant natural law. It converges with Thomistic natural law theory in that theory's three-fold assertion: 1) natural law is a 'living response of reflective intellects of any age to the implications of human experience,' 2) 'the structure of the being which acts determines the structure of the being's activity, and therefore this activity develops, fulfills, and perfects being,' 3 ) that 'because man is an intelligent and free creature, the natural law for man is a moral law, that is, a law which he discerns and freely accepts or rejects'. ${ }^{47}$ It diverges from the Thomistic model in that it keeps a very strong break between nature and revelation, in that it is a tool for the discernment of the moral law and can operate freely and flexibly in a religiously plural environment. It may be rightly part of the Protestant tradition at the very least in that it harnesses exigencies of Protestant Christianity to form a new 
means to address these exigencies.

Looking at the heritage of Scottish rhetoric in this way adds yet another dimension to its complicated trajectories. This points to a final concluding remark on the tensions that are always at work between theory and practice, and the possibilities that this tension affords to Scottish philosophy, if the case of the Scottish rhetoric is examined as its deeply theorized practical development. 


\section{References}

Agnew, Lois (1998) 'The Civic Function of Taste: A Re-assessment of Hugh Blair's Rhetorical Theory', Rhetoric Society Quarterly, 28(2): 25-36.

Bain, Alexander [1877] (2005) English Composition and Rhetoric, London:

Longmans, Green, and Co., Elibion Classics Replica Edition, Elibron Classics Series.

Berlin, James (1987) Rhetoric and Reality, Carbondale: Southern Illinois University Press

Bitzer, Lloyd (1969) 'Hume’s Philosophy' in George Campbell's Philosophy of Rhetoric', Philosophy and Rhetoric, 2(3): 139-66. . (1988) 'Introduction' to The Philosophy of Rhetoric by George Campbell

[1776], Carbondale: Southern Illinois University Press. . (1962) ‘The Lively Idea: A Study of Hume’s Influence on George Campbell's

Philosophy of Belief', PhD Dissertation, State University of Iowa.

Bizzell, Patricia and Bruce Hertzberg (1990) The Rhetorical Tradition, New York: Bedford Press.

Blair, Hugh [1783] (2005) Lectures on Rhetoric and Belles lettres, ed. Linda FerreiraBuckley and S. Michael Halloran, Carbondale: Southern Illinois University Press.

Campbell, George [1776] (1988) The Philosophy of Rhetoric, ed. Lloyd Bitzer, Carbondale: Southern Illinois University Press.

Casey Michael W. (2004) “'Come Let Us Reason Together”: The Heritage of the 
Churches of Christ as a Source for Rhetorical Invention', Rhetoric \& Public Affairs, 7.4 (Winter): 487-98.

— (2001) 'From British Ciceronianism to American Baconianism: Alexander Campbell as a Case Study of a Shift in Rhetorical Theory', Southern Communication Journal, 66.2 (Winter): 151-67.

Coady, C. A. J. (2004) 'Reid and the Social Operations of the Mind', in Terrence Cuneo and Rene Van Woudenberg (eds), The Cambridge Companion to Thomas Reid, Cambridge: Cambridge University Press.

Conley, Thomas (1990) Rhetoric in the European Tradition, Chicago: University of Chicago Press.

Cuneo, Terrence and Rene Van Woudenberg (2004) 'Introduction', in Terrence Cuneo and Rene Van Woudenberg (eds), The Cambridge Companion to Thomas Reid, Cambridge: Cambridge University Press.

Daiches, David (1990) 'STYLE PERIODIQUE and STYLE COUPE: Hugh Blair and the Scottish Rhetoric of Independence', in Richard Sher and Jeffery Smitten (eds), Scotland and America in the Age of Enlightenment, Princeton: Princeton University Press.

Dewey, John [1910] (1993) Philosophy and Education in their Historic Relations; transcribed from his lectures by Elsie Ripley Clapp, ed. J. J. Chambliss, Boulder: Westview Press.

[1900] (1990) The School and Society and the Child and the Curriculum, Chicago: Chicago University Press.

Diamond, Peter J. (1993) 'Rhetoric and Philosophy in the Social Thought of Thomas 
Reid', in J Dwyer, John and Richard B. Sher (eds), Sociability and Society in Eighteenth Century Scotland, Edinburgh: Mercat Press.

Dwyer, John, (1993) 'Introduction - A Peculiar Blessing: Social Converse in Scotland from Hutcheson to Burns', in John Dwyer and Richard B. Sher (eds), Sociability and Society in Eighteenth Century Scotland, Edinburgh: Mercat Press.

Gaillett, Lynee Lewis (ed.) (1998) Scottish Rhetoric and Its Influences, Matwah, NJ: Hermagoras/Erlbaum.

Golden, James L., and Edward P. J. Corbett (1990) The Rhetoric of Blair, Campbell, and Whately, Carbondale: Southern Illinois University Press.

Hanvelt, Marc (2012) The Politics of Eloquence, Toronto: Toronto University Press. Herdt, Jennifer (1994) 'Fatal Divisions: Hume on Religion, Sympathy, and the Peace of Society', PhD Dissertation, Princeton University.

Herrick, James A. (2001) The History and Theory of Rhetoric: An Introduction, Boston: Allyn and Bacon.

Howell, Wibur Samuel (1956) Logic and Rhetoric in England, 1500-1700, Princeton: Princeton University Press.

Hume, David (1999) An Enquiry Concerning Human Understanding, ed. Tom Beauchamp, Oxford: Oxford Philosophical Texts.

Kennedy, George A. (1999) Classical Rhetoric and its Christian and Secular Tradition, from Ancient to Modern Times, 2nd edition, Chapel Hill: University of North Carolina Press.

Kozinski, Thaddeus (2010) The Political Problem of Religious Pluralism and Why 
Philosophers Can't Solve It, Lanham, MD: Rowman \& Littlefield.

Lauer, Janice (2004) Invention in Rhetoric and Composition, West Lafayette, Indiana:

Parlor Press and the WAC Clearinghouse.

Liszka, James Jakob (2010) 'Peirce's Revolutionary Concept of Rhetoric', Nordic Studies in Pragmatism 2010, Helsinki University.

Miller, Thomas P. (1990) 'Witherpoon, Blair and the Rhetoric of Civic Humanism', in Richard Sher and Jeffery Smitten (eds), Scotland and America in the Age of Enlightenment, Princeton: Princeton University Press.

MacIlmaine, Roland [1574] (1969) 'Introduction to Ramus' Logike', in The Logike of Peter Ramus, tran. Roland Mac Ilmaine, ed. Catherine Dunn, Northridge, CA: San Fernando Valley State College.

MacIntyre, Alistair (1988) Whose Justice, Which Rationality?, South Bend: Notre Dame University Press.

Monsma, Stephen V., and J. Christopher Soper (2009) The Challenge of Pluralism: The Church and State in Five Democracies, Lanham, MD: Rowman \& Littlefield.

Gauvreau, Michael (1994) 'The Empire of Evangelicalism: Varieties of Common Sense in Scotland, Canada, and the United States', in Mark A. Noll, David William Bebbington, and George A. Rawlyk, (eds), Evangelicalism: Comparitive Studies of Popular Protestantism in North America, the British Isles, and beyond, 1700-1900, Oxford: Oxford University Press.

Peirce, Charles Sanders [1871] (1992) 'Fraser's 'The Works Of George Berkeley", in Nathan Houser and Christian Kloesel (eds.) The Essential 
Peirce: Selected Philosophical Writings, Volume I (1867-1893), Bloomington: Indiana University Press.

_ [1877] (1992) 'The Fixation of Belief', in Nathan Houser and Christian Kloesel (eds.), The Essential Peirce: Selected Philosophical Writings, Volume I (18671893), Bloomington: Indiana University Press.

Regan, Richard (1963) American Pluralism and Catholic Conscience, New York: Macmillan Company.

Reid, Thomas [1785] (2002) Essays on the Intellectual Powers of Man, ed. Derek R. Brookes, University Park, PA: Pennsylvania State University Press. Skopec, Eric Wm. (1978) 'Thomas Reid's Fundamental Rules of Eloquence', Quarterly Journal of Speech, 64(4): 400-8.

Sher, Richard (1990) 'Introduction: Scottish-American Cultural Studies, Past, Present', in Richard Sher and Jeffery Smitten (eds), Scotland and America in the Age of Enlightenment, Princeton: Princeton University Press.

Short, Brian (2000) 'Figurative Language and the Scottish New Rhetoric', Language Sciences, 22(3): 251-64.

Simpson, Matthew (2003) “"Hame Content”: Globalisation and a Scottish Poet of the Eighteenth Century', Eighteenth-Century Life, Winter 27(1): 107-30.

Warnick, Barbara (1993) The Sixth Canon: Belletristic Rhetoric and Its French Antecedents, Columbia: University of South Carolina Press.

Wolf, Donald, S. J. (1968) Toward Consensus: Catholic-Protestant Interpretations of Church and State, New York: Anchor Books.

Zuckert, Catherine (2011) 'Introduction: Political Philosophy in the Twentieth 
Century', in Catherine Zuckert (ed.), Political Philosophy in the Twentieth Century: Authors and Arguments, Cambridge: Cambridge University Press. Zuckert, Michael (1996) The Natural Rights Republic: Studies in the Foundation of the American Political Tradition, Notre Dame: Notre Dame University Press. 


\section{Notes}

${ }^{1}$ Lauer (2004): 39.

${ }^{2}$ Conley (1990): 223.

${ }^{3}$ America, of course, has a more thorough and earlier engagement with the issues of religious pluralism, and here, too, Scottish Common Sense philosophy, and perhaps more pointedly, rhetoric, does indeed play an inestimable role in that engagement. ${ }^{4}$ It may be partly because so much Scottish Common Sense thinking was specifically addressed to Humean skepticism that there may be found this anticipatory gesture. It is certainly not because any one of the Common Sense school would have foreseen, desired, or anticipated a fully pluralist society, much less a secular state. As Jennifer Herdt, in her dissertation on Hume, points out, after the religious wars of the sixteenth and seventeenth centuries: 'There was an urgent need for shared vocabularies in which to conceive of human society and common welfare beyond the boundaries of sectarian identities and loyalties... Many of the key figures in this process of secularization were, of course, themselves religious, and held beliefs about the particular nature of the deity and the appropriate way in which to worship and to serve such a deity. Nevertheless, for strategic purposes they employed non-sectarian justifications for their public social and political social proposals' (Herdt, 1994, vii-viii). Many of the Moderati were very much in this mold. I am using the term 'secular' here and elsewhere to refer to the fact that methodology and theory are capable of operating outside of specifically religiously-inflected discourse, and am not meaning to imply the wider dimensions of more contemporary invocations of secularism as an ideological or political position. As with the term 'secular' used in this context, by 
'pluralism' here I refer to the more limited form of pluralism found in eighteenthcentury Scotland. The author is gratefully indebted to the anonymous referee of this journal for pointing out the need for clarification of this point.

${ }^{5}$ Bitzer (1963): xxi.

${ }^{6}$ Hanvelt (2012): 104.

${ }^{7}$ On Eloquence, his most famous and direct writing on the subject, treats the art of oratory exclusively. While this is certainly not outside of the realm of rhetoric, it is not a treatment of Hume's theory of language use in his moral or mental economy. ${ }^{8}$ Bitzer (1962): 45.

${ }^{9}$ This is also following the classical traditions (roundly rejected by Ramus) of Aristotle, Cicero and Quintillian, of which they were all very familiar.

${ }^{10}$ Hume, Enquiry: 5.1.6.

${ }^{11}$ Hanvelt, 105.

12 The details of the full extent of the correspondence of the philosophy of mind in Hume and Campbell, including many instances of almost exactly the same wording, can be found in Lloyd Bitzer (1969) 'Hume's Philosophy' in George Campbell's Philosophy of Rhetoric', Philosophy and Rhetoric, 2(3): 139-66.

13 Ibid, 161.

14 The author would like to warmly thank an anonymous referee of this journal, for suggesting clarification of this point.

${ }^{15}$ Campbell (1988): 73.

16 'Introduction', p. 1xxiii.

17 Ibid, p. lxxiv. 
18 Ibid, p. lxxv.

19 Ibid, p. 32

20 Ibid, p. 34.

21 This is often explained as spherical or spirical, as opposed to circular. That is, the process repeats, as in a circular motion, but ends at a different point on the sphere, as in a spiral. Another way to describe this is a process of refraction: in which, like a mirror held up to an image, a process is used to reflect both the content and the process at once.

22 Ibid, p. 46.

${ }^{23}$ Blair, Lectures in Rhetoric and Belles lettres, 'Lecture I', p. 3.

${ }^{24}$ Blair, 'Lecture 3', p. 21.

25 Blair, 'Lecture 2', p. 19.

${ }^{26}$ Bain is rarely included in discussions of Scottish Enlightenment philosophy, as of course his lifetime falls outside of the Enlightenment period, and his own philosophy incorporates many later developments and influences, diverging from Common Sensism in substantial ways. For the purposes of Scottish rhetoric, however, for reason of both ideational continuity and the practical influence of his rhetorical textbooks, he is easily included.

${ }^{27}$ Bain, Alexander, English Composition and Rhetoric, p. 150.

28 Ibid.

29 Ibid, 176.

30 Ibid.

31 Ibid, 176. 
32 Ibid, 186.

${ }^{33}$ Ibid.

34 Diamond (1993): 71.

35 Ibid.

${ }^{36}$ Reid: $58-9$.

${ }^{37}$ Reid: $57-77$.

${ }^{38}$ Hume rejected the key premise of providential design, the Common Sense thinkers did not - it is for future work to make a genuine inquiry of the theological implications of the rhetorical theory I am here describing. One of the implications is that, theologically, where Hume finds a final resolution in skepticism that we can know a truth in its finality, Common Sense realism finds grounds for the Christian assertion of the infinite, or expansive nature of the Creator, and therefore, of knowledge of truth. Both agree that we cannot really know, the former because true knowledge is impossible, the latter because it is infinite, and thus outside our capacities. ${ }^{39}$ See the work of James Berlin (particularly James Berlin (1987) Rhetoric and Reality, Carbondale: Southern Illinois University Press) to explain this term and its historicisation within U.S. Composition studies.

${ }^{40}$ Peirce, C. S. (1878) 'How to Make Ours Ideas Clear', p. 140.

${ }^{41}$ Liszka (2010): 130.

${ }^{42}$ I do not mean to imply that Peirce's work is correlative with the work it produced in his followers and contemporaries. To a large degree, to the contrary. 43 Wolf (1968): 179.

${ }^{44}$ Monsma and Soper (2009): 3. 
${ }^{45}$ Wolf (1968): 278.

46 MacIntyre (1988): 375.

47 Regan (1963): 189-91. 